\title{
Harmonisation of stem volume estimates in European National Forest Inventories
}

\author{
Thomas Gschwantner ${ }^{1} \cdot$ Iciar Alberdi $^{2}$ - András Balázs ${ }^{3}$ - Sébastien Bauwens ${ }^{4} \cdot$ Susann Bender $^{5}$. Dragan Borota $^{6}$. \\ Michal Bosela ${ }^{7,8}$. Olivier Bouriaud ${ }^{9} \cdot$ Isabel Cañellas ${ }^{2} \cdot$ Jānis Donis $^{10}$ - Alexandra Freudenschuß ${ }^{1}$. \\ Jean-Christophe Hervé ${ }^{11}$ • David Hladnik ${ }^{12,13}$. Jurǵis Jansons ${ }^{10} \cdot$ László Kolozs $^{14} \cdot$ Kari T. Korhonen $^{3}$ • Milos Kucera ${ }^{15}$. \\ Gintaras Kulbokas ${ }^{16,17}$. Andrius Kuliešis ${ }^{16,17}$. Adrian Lanz ${ }^{18} \cdot$ Philippe Lejeune $^{4} \cdot$ Torgny Lind $^{19} \cdot$ Gheorghe Marin $^{9}$. \\ François Morneau ${ }^{20}$. Dóra Nagy ${ }^{14}$. Thomas Nord-Larsen ${ }^{21}$ • Leónia Nunes ${ }^{22}$ • Damjan Pantić ${ }^{6}$. Joana A. Paulo ${ }^{23}$. \\ Tomas Pikula $^{15}$ • John Redmond ${ }^{24}$ • Francisco C. Rego ${ }^{22} \cdot$ Thomas Riedel $^{5} \cdot$ Laurent Saint-André $^{25}$. Vladimír Šebeň ${ }^{7}$. \\ Allan Sims ${ }^{26}$. Mitja Skudnik ${ }^{13}$ - György Solti ${ }^{14}$ - Stein M. Tomter ${ }^{27} \cdot$ Mark Twomey $^{24} \cdot$ Bertil Westerlund $^{19}$. \\ Jürgen Zell ${ }^{18}$
}

Received: 28 March 2018 / Accepted: 11 January 2019 / Published online: 28 February 2019

(C) The Author(s) 2019

\begin{abstract}
- Key message Volume predictions of sample trees are basic inputs for essential National Forest Inventory (NFI) estimates. The predicted volumes are rarely comparable among European NFIs because of country-specific dbh-thresholds and differences regarding the inclusion of the tree parts stump, stem top, and branches. Twenty-one European NFIs implemented harmonisation measures to provide consistent stem volume predictions for comparable forest resource estimates. - Context The harmonisation of forest information has become increasingly important. International programs and interest groups from the wood industry, energy, and environmental sectors require comparable information. European NFIs as primary source of forest information are well-placed to support policies and decision-making processes with harmonised estimates.

- Aims The main objectives were to present the implementation of stem volume harmonisation by European NFIs, to obtain comparable growing stocks according to five reference definitions, and to compare the different results.

- Methods The applied harmonisation approach identifies the deviations between country-level and common reference definitions. The deviations are minimised through country-specific bridging functions. Growing stocks were calculated from the unharmonised, and harmonised stem volume estimates and comparisons were made.
\end{abstract}

This article is part of the topical collection on Forest information for bioeconomy outlooks at European level

Contribution of the Authors

Coordination of harmonisation work: TG, AF

Harmonisation approach: OB, AF, TG, JCH, SBe, AL, TR, LSA

Testing of the harmonisation approach: AB, TG, KTK, JR, MT

Contribution of bridging functions: IA, AB, SBa, MB, OB, IC, TG, JCH, KTK, MK, PL, FM, TNL, LN, TP, JR, FCR, VS, SMT, MT, JZ

Harmonisation work at country level: all authors

Developing the manuscript: IA, SBa, MB, TG, TNL, LN, MS

Writing the manuscript: TG

Revising the manuscript: all authors

Literature review: IA, TG, DH, LK, KTK, GK, AK, TNL, LN, DP, FCR, SMT

In memory of Jean-Christophe Hervé

Our work-package leader, colleague and dear friend Jean-Christophe Hervé passed away during the project period. He greatly supported and significantly contributed to the harmonisation activities of our group, and to the scientific work of ENFIN. We remember his scientific expertise and dedication, his visionary spirit and warm personality.

Handling Editor: John Moore

Thomas Gschwantner

thomas.gschwantner@bfw.gv.at

Extended author information available on the last page of the article 
- Results The country-level growing stock results differ from the Cost Action E43 reference definition between -8 and $+32 \%$. Stumps and stem tops together account for 4 to $13 \%$ of stem volume, and large branches constitute 3 to $21 \%$ of broadleaved growing stock. Up to $6 \%$ of stem volume is allocated below the dbh-threshold.

- Conclusion Comparable volume figures are available for the first time on a large-scale in Europe. The results indicate the importance of harmonisation for international forest statistics. The presented work contributes to the NFI harmonisation process in Europe in several ways regarding comparable NFI reporting and scenario modelling.

Keywords Sample-based inventories $\cdot$ dbh-threshold $\cdot$ Volume models $\cdot$ Reference definition $\cdot$ Growing stock $\cdot$ International reporting

\section{Introduction}

Volume predictions of sample trees are the basic inputs for essential National Forest Inventory (NFI) estimates such as growing stock, increment, and fellings. The NFI estimates derived from sample tree volumes serve many information needs at country and international levels including the availability and use of wood resources (Bosela et al. 2016; European Parliament and Council of the European Union 2009; UNECE/FAO 2011; Vidal et al. 2016a), sustainable forest management (FOREST EUROPE, UNECE and FAO 2011; FOREST EUROPE 2015), greenhouse gas (GHG) reporting (Dunger et al. 2012; IPCC 2006; United Nations 1992; United Nations 1998) and biodiversity (EC 2003; European Commission 2015; McRoberts et al. 2012; Winter et al. 2008). International programs like the Forest Resources Assessment (FRA) of the United Nations Food and Agriculture Organisation (FAO) and the assessment of the Status of Europe's Forest (SoEF) of FOREST EUROPE require forest information about e.g. growing stock, biomass, carbon and wood removals at periodic intervals of about 5 years (FAO 2015; FOREST EUROPE 2015).

NFIs in Europe were established at different time periods in the twentieth and twenty-first centuries. They were primarily motivated by country-level information needs such as forest management planning and forest industry planning in Nordic countries, and monitoring sustainable forest utilisation in central Europe (Tomppo et al. 2010b). Tomppo et al. (2010a) and Vidal et al. (2016a) give a comprehensive overview about NFIs including information about data collection and estimation methods. The different NFI features often have been developed to accommodate the unique topographies, climates, forest types and commercial interests in the countries (McRoberts et al. 2010). As a consequence, forest resource information at the European level displays a lack of comparability across country borders.

To achieve comparability in forest resources information in Europe, a harmonisation process was launched in the 1990s with the establishment of the European Forestry Information and Communication System EFICS (1997). The EFICS study collected information about the methods used for forest resource assessments in EU and EFTA countries, analysed the differences among the existing inventory systems, and carried out an information needs assessment. The Global Forest
Resources Assessment FRA 2000 (FAO 2001) and its regional contribution TBFRA (UNECE/FAO 2000) were the first assessments to use a homogenous set of definitions, including definitions for growing stock and standing volume. These definitions were revised in the subsequent FRAs (compare FAO 2004, 2010, 2012a) which further contributed to the harmonisation of NFIs. The importance of harmonisation is expressed in the long-term strategy of FRA reporting in FAO (2012b). Vidal et al. (2016b) provide a comprehensive review on the role of NFIs in international reporting processes and the challenges associated with the lack of comparability.

In the early 2000s, European NFIs formed the European National Forest Inventory Network (ENFIN 2018) to exchange knowledge, cooperate and promote NFIs as comprehensive monitoring systems by harmonising information on forest ecosystems. This led among other things to two successive COST Actions, E43 (2010) and FP1001 (2014). COST Action E43 (2010) built upon and integrated the previous harmonisation efforts of EFICS (1997), FAO (2001) and UNECE/FAO (2000) by establishing a general harmonisation approach for European NFIs that relies on common reference definitions and bridging functions (Tomppo and Schadauer 2012).

As methodological contribution to NFI harmonisation, Ståhl et al. (2012) presented a framework for constructing bridging functions and distinguished between two main levels at which bridging functions can be applied: the level of individual sampling units like sample trees and sample plots, or aggregate levels of country- or sub-country-level results. Different examples of bridging functions for harmonising growing stock estimates were presented by Tomter et al. (2012) for Finland, Germany, Italy, Lithuania, Norway and Sweden, and by Ståhl et al. (2012) for Belgium. A harmonised definition and bridging functions for above-ground biomass were recently implemented by 26 European NFIs to obtain comparable estimates at country- and sub-country levels (Henning et al. 2016; Korhonen et al. 2014).

Deviations in volume and biomass estimates of European NFIs are mainly caused by country-specific thresholds for the diameter at breast height (dbh) for sample tree selection, and the inclusion or exclusion of tree parts like stump, stem top or branches in the volume predictions for sample trees. For example, different dbh-thresholds between 0 and $12 \mathrm{~cm}$ can lead 
to an underestimation of volume estimates by $0.7-16.1 \%$ (Cienciala et al. 2008; Kuliešis and Kulbokas 2009; Mantau et al. 2016). Stumps are reported to account for 1.8 to $3.3 \%$ of the stem (Hladnik and Kobal 2012; Mantau et al. 2016), and branches of hardwoods together with stem tops contribute $21.6 \%$ of the above-ground biomass (Mantau et al. 2016). These figures suggest substantial discrepancies in the volume estimates of European NFIs; however, an evaluation at European scale has not been performed until now.

Under the Horizon 2020 project entitled "Distributed, Integrated and Harmonised Forest Information for Bioeconomy Outlooks" (DIABOLO 2015), the harmonisation process of European NFIs has continued. In order to improve the information about European forest resources, harmonisation measures were implemented by 21 NFIs to obtain harmonised stem volume estimates. The objectives of the present work are to demonstrate the implementation of stem volume harmonisation and the involved approaches, to calculate comparable growing stock estimates according to the reference definition of Cost Action E43 (2010) and four alternative reference definitions, and to conduct comparisons between the different growing stock results in order to quantify the impact of deviations from the reference definition of Cost Action E43 (2010), to evaluate the percentage of the merchantable stem part, and the contribution of the stump, stem top, trees below the dbh-threshold and large branches. The results are discussed along the objectives of this work and brought into context with the overall NFI harmonisation process in Europe.

\section{Material and methods}

The harmonisation of stem volumes was accomplished under the framework conditions given by the existing data sources and volume models within the NFIs as well as the general harmonisation method established for European NFIs (McRoberts et al. 2010; Tomppo and Schadauer 2012; Vidal et al. 2008). Thus, firstly, the NFIs as data basis for harmonisation are described with an emphasis on the differences relevant for harmonisation. Secondly, the harmonisation approach with the established reference definitions and applied bridging functions are specified. And thirdly, the implementation of stem volume harmonisation by European NFIs, its components and the performed calculations are presented.

\subsection{National Forest Inventories}

\subsubsection{General NFI features}

The harmonisation of stem volume estimates involved samplebased NFIs from 21 European countries: Austria (AT), Belgium (BE), Czech Republic (CZ), Denmark (DK), Estonia (EE), Finland (FI), France (FR), Germany (DE), Hungary (HU),
Ireland (IE), Latvia (LV), Lithuania (LT), Norway (NO), Portugal (PT), Romania (RO), Serbia (RS), Slovakia (SK), Slovenia (SI), Spain (ES), Sweden (SE) and Switzerland $(\mathrm{CH})$. Together, these countries have a forest area of 145 million ha, a growing stock of 22,600 million $\mathrm{m}^{3}$ and fellings of 462 million $\mathrm{m}^{3}$ compared to an increment of 636 million $\mathrm{m}^{3}$ (FOREST EUROPE 2015), which, however, are not harmonised figures. Numerous features such as sampling grids, plot configurations, inventory cycles, sample tree selection methods, applied thresholds and the models used for volume estimation describe the methods of European NFIs (Tomppo et al. 2010a; Vidal et al. 2016a). An overview about the NFI sampling methods relevant for growing stock estimation is given in the Appendix Table 7. In total, the implementation of stem volume harmonisation is based on the sample tree data collected at approximately 390,000 NFI plot locations. In most cases, the plot design for sample tree selection are concentric circular plots and less frequently angle count samples or singular circular plots. In recent years, many NFIs have augmented their field data collection by integrating specific assessments about small trees $(0.0 \mathrm{~cm}<\mathrm{dbh}<\mathrm{dbh}$-threshold $)$. Usually, these assessments are stem counts by species and dbh-classes on additional small and often circular plots. In several instances, also height assessments are made for small trees.

\subsubsection{NFI features subject to harmonisation}

According to McRoberts et al. (2010), harmonisation seeks to maintain the framework of existing NFI methods. NFI features such as sampling designs and plot configurations often serve specific purposes, accommodate the unique forest conditions at country-level and thus justify their maintenance (McRoberts et al. 2010). A distinction of NFI features into ones that should be subject to the application of harmonisation measures and ones that are not was proposed by Gschwantner et al. (2016) for increment estimation. Similarly, the harmonisation of stem volume estimates focuses on the differences between NFIs regarding:

- Country-specific dbh-thresholds

- Tree parts included in the volume predictions of sample trees

- Thresholds for stem top diameter, branch diameter and stump height

Figure 1 shows the parts of a tree as defined for European NFIs (Gschwantner et al. 2009; Lanz et al. 2010) and the threshold values applied by the NFIs for volume estimation. The dbhthresholds range between 0.0 (minimum height $=1.3 \mathrm{~m}$ ) and $12.0 \mathrm{~cm}$, with $0.0 \mathrm{~cm}, 5.0 \mathrm{~cm}$, and $7.0 \mathrm{~cm}$ or $7.5 \mathrm{~cm}$ being the most frequent. The stem top diameter threshold is in most cases $0.0 \mathrm{~cm}$, meaning that the stem top is completely included in volume estimates. NFIs that exclude the stem top usually apply 

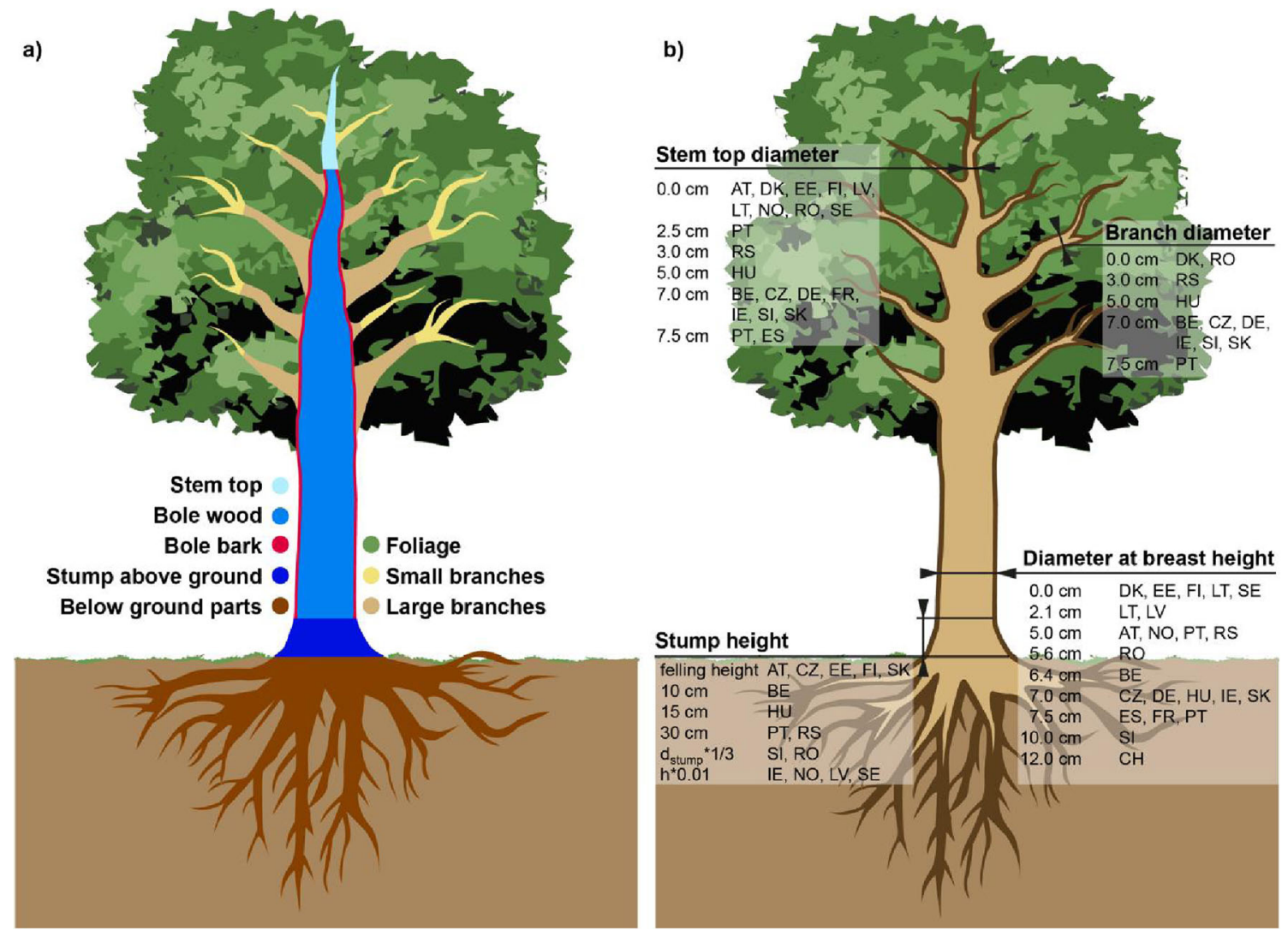

Fig. 1 a) Tree parts defined for European NFIs and b) threshold values applied for volume estimation (Gschwantner et al. 2009; Lanz et al. 2010)

a diameter threshold value of $7.0 \mathrm{~cm}$. Also the branch diameter threshold is in the majority of cases $7.0 \mathrm{~cm}$ when applicable. The stump height threshold is often defined rather general as "the height where the tree would be cut in felling". Several NFIs specify the felling height more concretely as for example by $1 \%$ of the tree height.

The differences in volume predictions originate from the dependent variables of the volume models applied by the NFIs to estimate the volume of individual sample trees. The volume models differ in terms of modelling concepts (e.g. taper curves, form factor functions, direct volume prediction), function types (e.g. power functions, exponential functions, linear combinations) and required input variables (e.g. species, dbh, height). The differences between the volumes predicted by the volume models of the 21 NFIs in terms of included tree parts are summarised in Table 1. Further details about the volume models including literature references are available in Appendix Table 8.

\subsection{Harmonisation approach}

\subsubsection{General harmonisation approach}

The general harmonisation approach established for European NFIs has two basic components: common reference definitions and bridging functions to convert estimates based on country-level definitions into estimates in accordance with common reference definitions (McRoberts et al. 2010; Tomppo and Schadauer 2012; Vidal et al. 2008). Thus, a definition-based method is applied in which the deviations between country-level and commonly agreed reference definitions are assessed and adjusted by bridging functions (Fig. 2). An estimate is considered to be harmonised when it is in line with the reference definition. Because both the country-level definitions and the European reference definitions for stem volume and growing stock are described by the same specific variables with specific thresholds, the deviations between them can be clearly identified and allow for the implementation of harmonisation measures.

\subsubsection{Reference definitions for harmonising stem volume estimates}

Reference definitions define the target object of interest (e.g. stem volume, growing stock) for the purpose of harmonisation (Vidal et al. 2008). A set of Europe-wide and commonly agreed reference definitions was developed during COST Action E43 (2010) which includes definitions for the volume of stems and growing stock, as well as for tree parts, thresholds and tree characteristics (Gschwantner et al. 2009; Lanz et al. 2010; see Appendix Table 9). According to these reference definitions of COST Action E43 (2010), growing stock aggregates the volume above stump height including the bole 
Table 1 Tree parts $K$ included in the country-level volumes $V c_{K}$ predicted for the sample trees by the 21 NFIs. Regarding threshold values for stump height $\left(h_{\text {stump }}\right)$, stem top diameter $\left(d_{\text {stem top }}\right)$ and branch diameter $\left(d_{\text {branch }}\right)$ refer to Fig. 1

\begin{tabular}{|c|c|c|c|c|c|c|c|}
\hline \multirow[t]{3}{*}{ Country-level definition No. } & \multicolumn{6}{|c|}{ Tree parts $K$ included in $V c_{K}$} & \multirow[t]{3}{*}{ Countries-NFIs } \\
\hline & \multirow{2}{*}{$\begin{array}{l}\text { Stump } \\
\left(h_{\text {stump }}\right)\end{array}$} & \multicolumn{2}{|l|}{ Bole } & \multirow{2}{*}{$\begin{array}{l}\text { Stem top } \\
\left(d_{\text {stem top }}\right)\end{array}$} & \multicolumn{2}{|l|}{ Branches } & \\
\hline & & Wood & Bark & & $\begin{array}{l}\text { Large } \\
\left(d_{\text {branch }}\right)\end{array}$ & $\begin{array}{l}\text { Small } \\
\left(d_{\text {branch }}\right)\end{array}$ & \\
\hline 1 & & $\mathrm{x}$ & $\mathrm{x}$ & & & & $\mathrm{BE}, \mathrm{IE}^{\mathrm{a}}, \mathrm{ES}$ \\
\hline 2 & & $\mathrm{x}$ & $\mathrm{x}$ & $\mathrm{x}$ & & & AT, EE, FI, LV, NO, SE \\
\hline 3 & $\mathrm{x}$ & $\mathrm{x}$ & $\mathrm{x}$ & & & & $\mathrm{FR}, \mathrm{DE}^{\mathrm{a}}, \mathrm{PT}^{\mathrm{c}}$ \\
\hline 4 & $\mathrm{x}$ & $\mathrm{x}$ & $\mathrm{x}$ & $\mathrm{x}$ & & & $\mathrm{DK}^{\mathrm{a}}, \mathrm{LT}, \mathrm{CH}, \mathrm{PT}^{\mathrm{d}}$ \\
\hline 5 & & $\mathrm{x}$ & & & $\mathrm{x}$ & & $\mathrm{CZ}, \mathrm{SK}$ \\
\hline 6 & & $\mathrm{x}$ & $\mathrm{x}$ & & $\mathrm{x}$ & & $\mathrm{HU}, \mathrm{IE}^{\mathrm{b}}, \mathrm{SI}$ \\
\hline 7 & $\mathrm{x}$ & $\mathrm{x}$ & & & $\mathrm{x}$ & & $\mathrm{PT}^{\mathrm{e}}$ \\
\hline 8 & $\mathrm{x}$ & $\mathrm{x}$ & $\mathrm{x}$ & & $\mathrm{x}$ & & $\mathrm{DE}^{\mathrm{b}}, \mathrm{PT}^{\mathrm{f}}, \mathrm{RS}$ \\
\hline 9 & & $\mathrm{x}$ & $\mathrm{x}$ & $\mathrm{x}$ & $\mathrm{x}$ & $\mathrm{x}$ & RO \\
\hline 10 & $\mathrm{x}$ & $\mathrm{x}$ & $\mathrm{x}$ & $\mathrm{x}$ & $\mathrm{x}$ & $\mathrm{x}$ & $\mathrm{DK}^{\mathrm{b}}$ \\
\hline \multicolumn{8}{|l|}{${ }^{\mathrm{a}}$ Conifers } \\
\hline \multicolumn{8}{|l|}{${ }^{\mathrm{b}}$ Broadleaves } \\
\hline \multicolumn{8}{|c|}{${ }^{\mathrm{c}}$ Other oaks and other broadleaves } \\
\hline \multicolumn{8}{|c|}{ ' Acacia sp., Castanea sativa, Eucalyptus globulus, Pinus pinaster, Pinus pinea, other conifers } \\
\hline \multicolumn{8}{|c|}{ 'Quercus suber } \\
\hline \multicolumn{8}{|l|}{ f Quercus ilex s.l. } \\
\hline
\end{tabular}

(wood and bark) and the stem top of trees above the dbhthreshold of $0 \mathrm{~cm}$ (height $>1.3 \mathrm{~m}$ ) that are living and standing or lying (Lanz et al. 2010) or only standing (Vidal et al. 2008).

Based on the already existing definitions, a more flexible scheme of reference definitions was established and agreed among the partner NFIs in the DIABOLO (2015) project. In order to fulfil different information needs, five different combinations of tree parts included in the volume predictions of individual sample trees were specified (Table 2). The dbhthreshold of $0 \mathrm{~cm}$ (height $>1.3 \mathrm{~m}$ ) of COST Action E43 (2010) was retained, and only standing and living trees were included in all five reference definitions. Diameter thresholds of $7 \mathrm{~cm}$ for the stem top and large branches, and stump heights according to felling practices in countries were defined. The

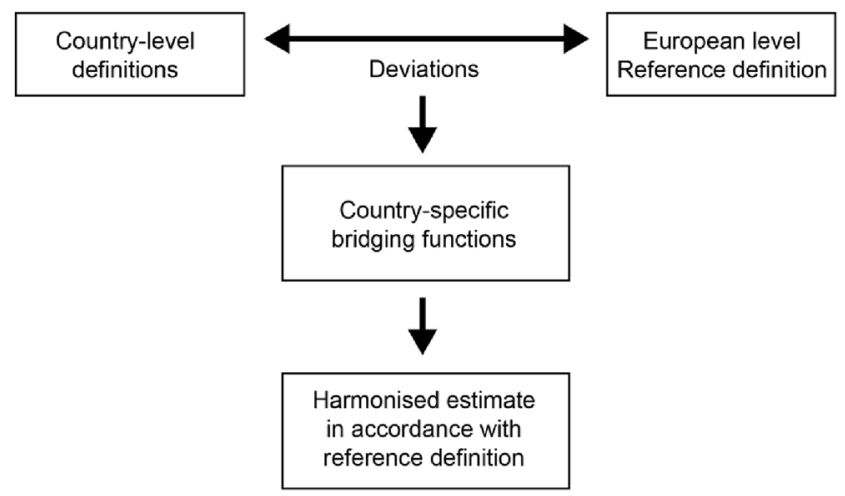

Fig. 2 Harmonisation approach for European NFIs reference definitions are named "Whole stem", "Cost Action E43", "Control", "Merchantable stem", and "Merchantable stem and branches". The definition "Cost Action E43" is identical to the reference definition of Cost Action E43 (2010), and the "Control" was introduced for result verification (Table 2).

\subsubsection{Bridging functions for harmonising stem volume estimates}

The bridging functions applied for stem volume harmonisation can be attributed to three groups of basic approaches: alternative volume models, complementary models and taper curve models (Table 3). As the NFIs differ considerably, also the bridging functions within the three groups vary in terms of model types and required variables. An overview about the bridging functions chosen and applied by the NFIs is available in Appendix Table 10. Sometimes a combination of the three basic approaches was used wherefore in these cases the bridging function considered as characteristic for the applied approach is given.

\subsection{Implementation of stem volume harmonisation}

\subsubsection{Components and workflow}

The implementation of harmonisation measures by the individual NFIs has three basic components, the NFI data-bases, the 
Table 2 Tree parts $K$ included in the five reference definitions $V r_{K}$ and the common threshold values for stump height $\left(h_{\text {stump }}\right)$, stem top diameter $\left(d_{\text {stem top }}\right)$ and branch diameter $\left(d_{\text {branch }}\right)$

\begin{tabular}{|c|c|c|c|c|c|c|c|c|}
\hline \multicolumn{2}{|c|}{ Reference definition } & \multicolumn{6}{|c|}{ Tree parts $K$ included in $V r_{K}$} & \multirow[t]{3}{*}{ Species group } \\
\hline \multirow[b]{2}{*}{ No. } & \multirow[b]{2}{*}{ Description } & \multirow{2}{*}{$\begin{array}{l}\text { Stump } \\
\left(h_{\text {stump }} \hat{=}\right. \\
\text { felling practices })\end{array}$} & \multicolumn{2}{|l|}{ Bole } & \multirow{2}{*}{$\begin{array}{l}\text { Stem top } \\
\left(d_{\text {stem top }}<7 \mathrm{~cm}\right)\end{array}$} & \multicolumn{2}{|l|}{ Branches } & \\
\hline & & & Wood & Bark & & $\begin{array}{l}\text { Large } \\
\left(d_{\text {branch }} \geq 7 \mathrm{~cm}\right)\end{array}$ & $\begin{array}{l}\text { Small } \\
\left(d_{\text {branch }}<7 \mathrm{~cm}\right)\end{array}$ & \\
\hline 1 & Whole stem & $\mathrm{x}$ & $\mathrm{x}$ & $\mathrm{x}$ & $\mathrm{x}$ & & & Conifers, broadleaves \\
\hline 2 & Cost Action E43 & & $\mathrm{x}$ & $\mathrm{x}$ & $\mathrm{x}$ & & & Conifers, broadleaves \\
\hline 3 & Control & $\mathrm{x}$ & $\mathrm{x}$ & $\mathrm{x}$ & & & & Conifers, broadleaves \\
\hline 4 & Merchantable stem & & $\mathrm{x}$ & $\mathrm{x}$ & & & & Conifers, broadleaves \\
\hline 5 & $\begin{array}{l}\text { Merchantable stem } \\
\text { and branches }\end{array}$ & & $\mathrm{x}$ & $\mathrm{x}$ & & $\mathrm{x}$ & & Broadleaves \\
\hline
\end{tabular}

program codes containing the volume models and up-scaling procedures, and the bridging functions that have to be integrated into the program codes (Fig. 3). The NFI data-bases contain sample tree-, stand- and site-specific data collected on the plots during the different NFI campaigns. An overview about the variables assessed by NFIs is available from the National Forest Inventory reports presented by Vidal et al. (2016a). The volume models of NFIs and also the bridging functions require mostly sample tree-specific data such as species, dbh and tree height as input for calculating stem volumes (Appendix Tables 8 and 10). The program codes contain the algorithms for calculating NFI estimates and include the volume models used by NFIs for stem volume estimation. The bridging functions were integrated in a separate set of program codes which process the NFI data. Un-harmonised and harmonised sample tree volumes were predicted and then upscaled to obtain growing stocks according to the country-level definitions, the reference definition of Cost Action E43 (2010) and the alternative reference definitions.

The bridging functions can have different forms depending on the type of volume model used by an NFI, the kind of existing NFI data and other available data sources. The bridging functions can originate from already existing models, the re-parameterisation of available models or the development of new models. The harmonisation in the DIABOLO (2015) project was facilitated and supported by a mutual exchange of bridging functions between NFIs. Consequently, the same deviation from the reference definition could be solved by more than one bridging function and required the choice of the most reliable option. Therefore, the bridging functions underwent an examination phase before their implementation. The choice of bridging functions was guided by the aim to avoid biased volume predictions.

\subsubsection{Target of implementing stem volume harmonisation}

The estimation of growing stock from sample tree volumes requires additional tree characteristics to define the target object within the population of perennial woody plants (Vidal et al. 2008). According to reference definition of COST Action E43 (2010), shrub species and dead trees do not belong to growing stock and therefore were excluded from the calculations. Lying

Table 3 Approaches of bridging functions applied by the 21 NFIs

\begin{tabular}{|c|c|}
\hline Approach & Description \\
\hline Alternative model & $\begin{array}{l}\text { Refers to volume models that are additionally used by NFIs to predict other than the national stem volume estimates by including or } \\
\text { excluding the desired tree parts. Such alternative volume models are used by NFIs to satisfy different information needs about } \\
\text { e.g. merchantable volume, volume under- or over-bark, or tree volume including branches }\end{array}$ \\
\hline $\begin{array}{l}\text { Complementary } \\
\text { model }\end{array}$ & $\begin{array}{l}\text { The existing set of volume models applied by an NFI is complemented by additional models to predict the volume of the individual } \\
\text { tree parts stump, stem top and branches, or the trees below the dbh-threshold. Empirical models like allometric equations and } \\
\text { geometric approximations can be applied. The first are developed from field measurements, the second assume geometric bodies } \\
\text { (e.g. cone, cylinder, neiloid, paraboloid and truncates of them) and follow the idea of describing the stem shape by generic } \\
\text { conoids (Prodan 1965) }\end{array}$ \\
\hline Taper curve & $\begin{array}{l}\text { Taper curves describe the stem shape along the stem axis from the base point up to the stem tip and allow determining the stem } \\
\text { diameter at any specified height (e.g. stump height), or reversely the height for a specified diameter (e.g. stem top base diameter } \\
\text { of } 7 \mathrm{~cm} \text { ). Thus, taper curve models allow for deriving the volume for the whole stem, or defined stem segments which for } \\
\text { instance correspond to the reference definition }\end{array}$ \\
\hline
\end{tabular}




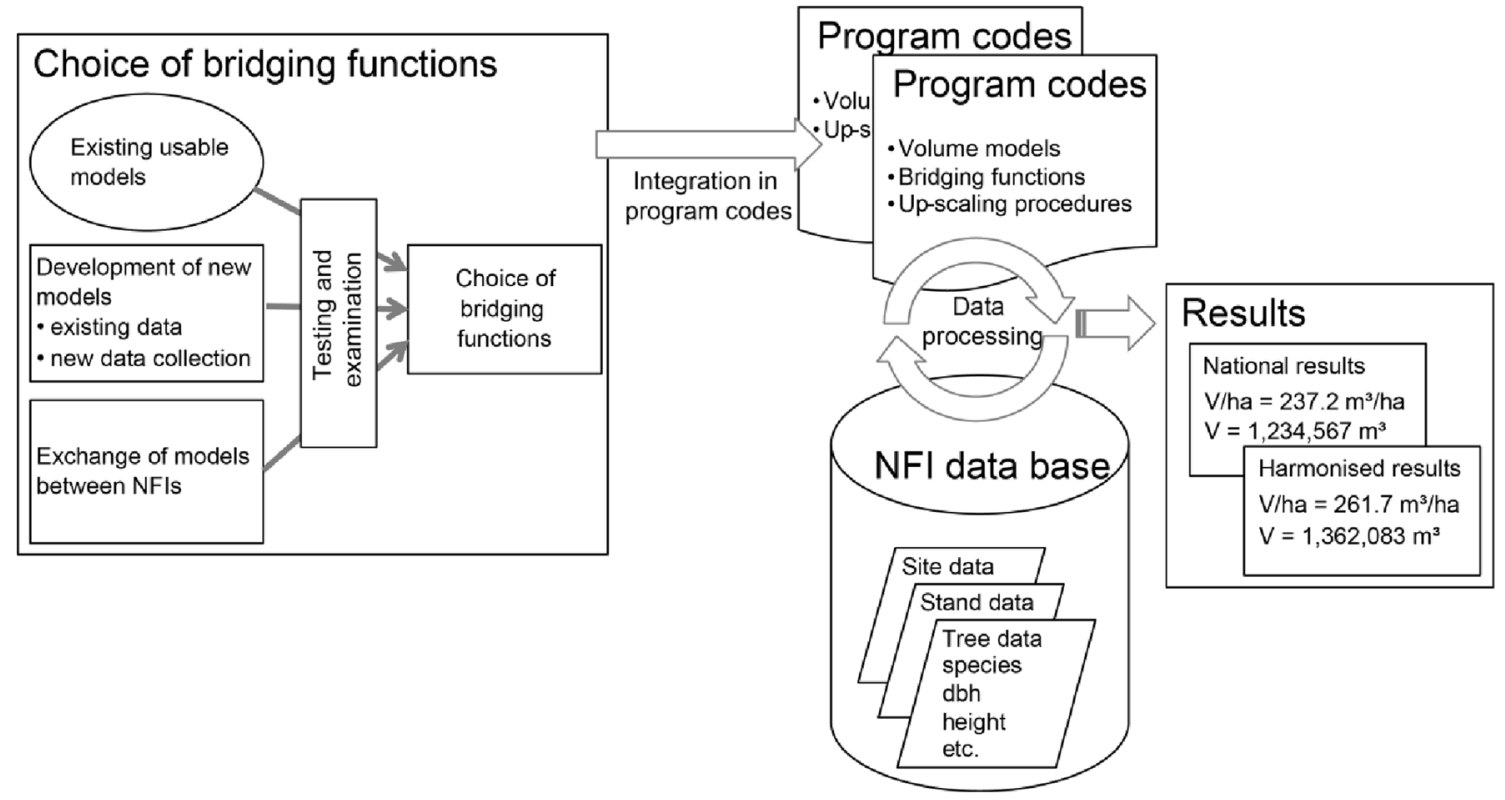

Fig. 3 Components of implementing the harmonisation of stem volume estimates

living trees may also be excluded (Vidal et al. 2008; Lanz et al. 2010). Since the majority of NFIs exclude lying living trees or can filter them out subsequently, these trees were not included in the calculated growing stocks. Thus, the calculated growing stocks include living and standing trees.

\subsubsection{Calculation of harmonised estimates}

In order to obtain un-harmonised and harmonised volumes of the individual sample trees, each NFI applied its volume models and in addition the chosen bridging functions. The calculations referred to standing and living trees. The volume according to a country-level definition $V c_{K}$ includes the tree parts $K$ (Table 1) of trees $\geq$ dbh-threshold and is predicted for the sample trees $i$ on the plots $j$ of country $c$ as function $f c_{K}$ of the variables $x_{c}$ :

$V c_{K}^{i, j}=f c_{K}\left(x_{c}\right)$

The volume according to a reference definition $V r_{K}$ includes the tree parts $K$ (Table 2) and is obtained differently depending on the applied approach of bridging functions. Approaches like taper curves or alternative volume models frequently predict $V r_{K}$ directly for the sample trees $i$ on the plots $j$ as function $f r_{K}$ of the variables $x_{r}$ :

$V r_{K}^{i, j}=f r_{K}\left(x_{r}\right)$

When complementary models are used, the harmonised volume $V r_{K}$ is usually obtained by bridging functions that predict the tree parts $k$ individually. Volume models for individual tree parts as e.g. branches require the addition of a bridging function $f r_{k}\left(x_{r}\right)$ to the country-level function $f c_{K}\left(x_{c}\right)$ to include the volume of tree part $k$

$V r_{K}^{i, j}=f c_{K}\left(x_{c}\right)+f r_{k}\left(x_{r}\right)$

or the subtraction of a bridging function $f r_{k}\left(x_{r}\right)$ from $f c_{K}\left(x_{c}\right)$ to exclude the volume of tree part $k$ :

$V r_{K}^{i, j}=f c_{K}\left(x_{c}\right)-f r_{k}\left(x_{r}\right)$

Complementary models that are volume expansion factors require the multiplication of the country-level function $f c_{K}\left(x_{c}\right)$ by the bridging function $f r_{k}\left(x_{r}\right)$ to include a particular tree part $k$

$V r_{K}^{i, j}=f c_{K}\left(x_{c}\right) * f r_{k}\left(x_{r}\right)$

or division of $f c_{K}\left(x_{c}\right)$ by the bridging function $f r_{k}\left(x_{r}\right)$ to reduce the volume by tree part $k$

$V r_{K}^{i, j}=\frac{f c_{K}\left(x_{c}\right)}{f r_{k}\left(x_{r}\right)}$

Complementary models that describe the ratio of individual tree parts (e.g. stump in relation to the whole stem) require the subtraction of the bridging function $f_{r_{k}}\left(x_{r}\right)$ from 1 and subsequent multiplication with $f_{c_{K}}\left(x_{c}\right)$ to exclude a particular tree part $k$ 
$V r_{K}^{i, j}=f c_{K}\left(x_{c}\right) *\left(1-f r_{k}\left(x_{r}\right)\right)$

or the subsequent division of $f_{c_{K}}\left(x_{c}\right)$ to include a tree part $k$

$V r_{K}^{i, j}=\frac{f c_{K}\left(x_{c}\right)}{\left(1-f r_{k}\left(x_{r}\right)\right)}$

NFIs that exclude small trees with $0<\mathrm{dbh}<\mathrm{dbh}$-threshold additionally apply a complementary bridging function $f r_{\text {small }}$ $\left(x_{r}\right)$ to estimate the stem volume $v r$ including the tree parts $K$ of the small trees $i_{\text {small }}$ on the plots $j$ in order to conform with the reference definition:

$v r_{K}^{i_{\text {small }}, j}=f r_{\text {small }, K}\left(x_{r}\right)$

After applying the bridging functions, the harmonised and un-harmonised sample tree volumes entered the countryspecific up-scaling procedures of growing stock estimation. The volumes of the individual sample trees are converted to values per hectare by applying the respective representation factor $b f_{i}$ for the sample tree $i$ and are aggregated for the sample plots $j$. For the country-level definition, the sample tree volumes per hectare represented by the sample plots $j$ is obtained by

$V c_{K}^{j} / h a=\sum_{i=1}^{n} V c_{K}^{i, j} * b f_{i}$

The sample tree volume per hectare according to the reference definition is calculated as the sum of trees $\geq$ dbh-threshold and trees $<\mathrm{dbh}$-threshold for sample plot $j$ as:

$V r_{K}^{j} / h a=\sum_{i=1}^{n} V r_{K}^{i, j} * b f_{i}+\sum_{i_{\text {small }}=1}^{n_{\text {small }}} v r_{K}^{i_{\text {small }}, j} * b f_{i_{\text {small }}}$

The country-level totals of growing stock are calculated by aggregating the sample tree volumes per hectare and plot, dividing by the number of sample plots $n_{j}$, and multiplying this mean volume per hectare with the area of the forest category relevant for growing stock $F_{g s}$. If the sampling intensity within a country is not constant, stratum-wise weighing factors need to be added in Eqs. (5) and (6).

$V c_{K}=\frac{\sum_{j=1}^{n} V c_{K}^{j} / h a}{n_{j}} * F_{g s}$

$V r_{K}=\frac{\sum_{j=1}^{n} V r_{K}^{j} / h a}{n_{j}} * F_{g s}$
The up-scaled growing stocks according to the countrylevel definition $V c_{K}$ and the reference definitions $V r_{K}$ (see Tables 1 and 2) were used for further calculations to obtain the difference compared to the reference definition of Cost Action E43 (2010), the percentage of the merchantable and non-merchantable stem part, and the volume share of merchantable branches:

Difference $(\%)=\frac{V c_{K}-V r_{K=2}}{V r_{K=2}} * 100$

Merchantable $(\%)=\frac{V r_{K=4}}{V r_{K=1}} * 100$

Non-merchantable $(\%)=\frac{V r_{K=1}-V r_{K=4}}{V r_{K=1}} * 100$

$\operatorname{Branches}(\%)=\frac{V r_{b l, K=5}-V r_{b l, K=4}}{V r_{b l, K=5}} * 100$

where $V c_{K}$ is the un-harmonised country-level growing stock, $V r_{K=1}$ is the growing stock including the whole stem, $V r_{K=2}$ is the growing stock according to the reference definition of Cost Action E43 (2010), $V r_{K=4}$ is the growing stock including the merchantable stem part above stump up to the stem top diameter of $7 \mathrm{~cm}, V r_{b l, K=4}$ is the broadleaved growing stock including the merchantable stem part, and $V r_{b l, K=5}$ including the merchantable stem and branches (see Table 2). The non-merchantable stem part was further differentiated into the stump and stem top. For $V r_{K=1}$, the percentage of trees below the dbhthreshold were calculated to estimate the contribution of this fraction.

\section{Results}

\subsection{Comparison with the Cost Action E43 reference definition}

The growing stocks according to the country-level definition and according to the Cost Action E43 (2010) reference definition are presented in Table 4 and reveal differences in the range from -8 to $+32 \%$. The magnitude of the differences depends on the kind of deviations between the country-level and the reference definition as subsequently described. The growing stocks of two NFIs (Finland, Sweden) correspond to the reference definition of Cost Action E43 (2010). The growing stocks of Austria, Latvia and Norway deviate only regarding the dbh-threshold and Estonia concerning the stump. In all other cases, the difference is the result of several partial deviations. Only positive deviations from the reference definition add up for the Danish NFI (stump, large branches), and only negative deviations for Belgium (dbh-threshold, 
stem top, young conifer stands excluded) and Spain (dbhthreshold, stem top). For the remaining NFIs, the differences result from positive and negative deviations. The positive deviations are either only due to branches (Czech Republic, Slovakia), only due to stumps (France, Lithuania and Switzerland), due to branches and stumps (Denmark, Germany, Portugal), or due to branches, stumps and standing dead trees (Serbia). These positive deviations are counterbalanced by negative deviations, either solely by the dbh-threshold (Lithuania, Romania, Serbia, Switzerland), by the dbh-threshold and the stem top (France, Germany, Hungary, Ireland, Portugal, Slovenia), or by the dbh-threshold, the stem top and the bark (Czech Republic, Slovakia).

\subsection{Comparison of merchantable stem volume}

The growing stocks including the whole stem volume as well as including only the merchantable part are presented in Table 5. The percentage of merchantable volume varies between 87 and $96 \%$. The lowest values were estimated for northern countries (Finland, Norway), southern Europe (Portugal, Spain, Serbia), the southwest (France) and the northwest of Europe (Ireland).

Reversely, the percentages of non-merchantable stem volume range between 4 and 13\%. The non-merchantable part is further differentiated into stumps and stem tops (Fig. 4). Stumps were estimated to contribute between 2 and $7 \%$ to the non-merchantable part, and stem tops about 1 and 9\%. The volume below the dbh-threshold was not differentiated for some NFIs due limits in the data. In these cases, the percentage of non-merchantable volume is slightly overestimated as it includes some stem volume thicker than the diameter threshold of $7 \mathrm{~cm}$. According to the NFIs of Belgium, Ireland and Slovenia, the trees below the dbh-threshold contribute $0.3 \%, 0.7 \%$ and $0.9 \%$ respectively, to the merchantable part.

Naturally, the lower size classes have the largest proportion of non-merchantable volume. Figure 5 shows the percentage of stem volume contributed by the trees below the dbh-thresholds applied by the 21 NFIs. Approximately around the dbh of $5.8 \mathrm{~cm}$, the stem base starts to exceed the diameter of $7 \mathrm{~cm}$. Thus, merchantable volume can be expected below the dbh-threshold when the thresholds of $6.4 \mathrm{~cm}$ and above are applied.

\subsection{Comparison of merchantable branch volume}

The growing stocks of broadleaves for merchantable stem volume and merchantable stem and branch volume are given in Table 6. Branches contributed 3-21\% to the merchantable growing stock of broadleaves. The Nordic and Baltic countries (Norway, Sweden, Latvia and Lithuania) showed a clearly lower percentage of branches.

\section{Discussion}

\subsection{Implementation of stem volume harmonisation}

The presented harmonisation of stem volume estimates was implemented on a large-scale by 21 European NFIs. It is the first evaluation of the harmonisation efforts and the consequences of deviations, including the breakdown into the individual causes of differences. As a basic feature, the applied harmonisation approach maintained the existing sets of volume models of NFIs and complemented them by bridging functions to account for the deviations from the reference definitions. The mathematical forms of the volume models are power functions, exponential functions or linear combinations that describe the stem taper and the form factor, or directly predict the stem volume. Usually the volume models of NFIs have been developed from quantitatively and qualitatively representative data sets collected in laborious field work campaigns by destructive sampling which are described in many of the references in Appendix Table 8. The volume models of NFIs were elaborated, tested and validated under the respective conditions at country-level and can be expected to give reliable predictions for the individual countries. Models tailored to address national circumstances are required for higher order methods in international reporting and provide greater certainty than the lower tier methods which use less detailed data and less advanced estimation procedures (IPCC 2006).

Depending on the respective situation regarding available data sources and implemented volume models, different approaches of bridging functions were applied by the NFIs. Among the presented groups of bridging functions, alternative volume models and taper curves are usually well-established in the respective NFIs and have been used and validated in earlier applications. Partly, this applies also to complementary models. However, several complementary models have been newly developed or were transferred from one NFI to another NFI with similar forest conditions. For the reason of such initial applications, the bridging functions were examined by the NFIs before integration into the estimation procedures to avoid biased volume predictions and to choose the most appropriate model among available options. The model examination includes comparisons with an independent data set, comparison with other models or expert knowledge if appropriate data are absent. According to Ståhl et al. (2012), the uncertainty of harmonised estimates depends on the harmonisation method applied. The different approaches of bridging functions applied in the presented work have their own specifics regarding the error of predicted sample tree 
Table 4 Growing stocks according to the country-level definitions and the reference definition of Cost Action E43 (2010), and the differences in percent $(\%)$

\begin{tabular}{|c|c|c|c|}
\hline \multirow[t]{2}{*}{ NFI-country } & \multicolumn{2}{|c|}{ Growing stock (million $\mathrm{m}^{3}$ ) } & \multirow[t]{2}{*}{ Difference $(\%)$} \\
\hline & $\begin{array}{l}\text { Country-level } \\
\text { definition }\end{array}$ & $\begin{array}{l}\text { Reference definition } 2 \\
\text { Cost Action E43 }\end{array}$ & \\
\hline Austria & 1106.5 & 1112.9 & -0.6 \\
\hline Belgium & 118.6 & 126.8 & -6.5 \\
\hline Czech Republic & 942.2 & 1028.0 & -8.3 \\
\hline Denmark & 133.1 & 110.7 & +20.2 \\
\hline Estonia & 476.0 & 462.4 & +3.0 \\
\hline Finland & 2343.4 & 2343.4 & 0.0 \\
\hline France & 2566.5 & 2757.0 & -6.9 \\
\hline Germany & 3367.5 & 3185.8 & +5.7 \\
\hline Hungary & 390.4 & 352.7 & +10.7 \\
\hline Ireland & 97.5 & 99.4 & -2.0 \\
\hline Latvia & 660.3 & 660.9 & -0.1 \\
\hline Lithuania & 542.7 & 535.0 & +1.4 \\
\hline Norway & 1094.4 & 1126.3 & -2.8 \\
\hline Portugal & 158.1 & 179.4 & -11.9 \\
\hline Romania & 2156.5 & 1961.1 & +10.0 \\
\hline Serbia & 375.1 & 284.5 & +31.9 \\
\hline Slovakia & 569.5 & 608.8 & -6.4 \\
\hline Slovenia & 416.8 & 403.9 & +3.2 \\
\hline Spain & 1001.2 & 1088.5 & -8.0 \\
\hline Sweden & 3493.5 & 3493.5 & 0.0 \\
\hline Switzerland & 409.7 & 408.2 & +0.4 \\
\hline
\end{tabular}

volumes. Taper curve or alternative volume approaches can be supposed to have similar prediction errors at individual tree level for the un-harmonised and harmonised stem volume estimates. Because the original volume model and the bridging function are based on the same data set, no additional error sources are incurred by these approaches. Combining the existing country-level volume models with complementary models derived from other data sets can cause additivity issues for the volume predictions at sample tree level. Although the examination of bridging functions minimised such biases in the volume predictions, these effects cannot be completely excluded especially for sample trees outside the data range of model parameterisation.

The bridging functions applied by the 21 NFIs solved all major and most minor deviations from the growing stock reference definitions. In some cases, minor deviations had to be accepted due to limits in the available data and models. For example, the stem volume below the dbh-threshold was not always differentiated into the merchantable and nonmerchantable parts (France, Germany, Hungary, Portugal, Slovakia, Spain), the volume of branches was not calculated for two countries (Finland, Estonia), stem top or branch diameter thresholds other than $7 \mathrm{~cm}$ were applied (Portugal, Spain, Estonia), recently died trees were not excluded from growing stock (Germany, Serbia), lying living trees could not be excluded from growing stock (Belgium, Denmark, Finland, Serbia, Slovenia), and shrubs were not excluded based on the species but on the dbh-threshold (Belgium). However, the harmonisation of NFIs is a process of continuous improvement of methods, data collection and data analysis (Vidal et al. 2016b). As additional data become available, the approaches for harmonising stem volume estimates can be further enhanced.

\subsection{Comparable growing stock estimates according to five reference definitions}

The development of the reference definitions for stem volumes and growing stock during COST Action E43 (2010) was motivated by the idea to have one unique definition as basis for common reporting. As the demands for forest information for international processes increase and information needs are diversifying, a more flexible scheme of reference definitions was established. The flexibilisation was motivated by several considerations regarding the volume contribution of the individual tree parts stump, stem top and large branches, and the merchantable part of growing stock. 
Table 5 Growing stocks for the whole stem and the merchantable stem part, and the percentages of merchantable volume (\%)

\begin{tabular}{|c|c|c|c|}
\hline \multirow[t]{2}{*}{ NFI - country } & \multicolumn{2}{|c|}{ Growing stock (million $\mathrm{m}^{3}$ ) } & \multirow{2}{*}{$\begin{array}{l}\text { Percentage of } \\
\text { merchantable } \\
\text { volume }(\%)\end{array}$} \\
\hline & $\begin{array}{l}\text { Reference definition } 1 \\
\text { Whole stem }\end{array}$ & $\begin{array}{l}\text { Reference definition } 4 \\
\text { Merchantable stem }\end{array}$ & \\
\hline Austria & 1159.7 & 1087.0 & 93.7 \\
\hline Belgium & 131.1 & 124.1 & 94.7 \\
\hline Czech Republic & 1050.2 & 1008.7 & 96.0 \\
\hline Denmark & 113.0 & 108.6 & 96.1 \\
\hline Estonia & 476.0 & 459.0 & 96.4 \\
\hline Finland & 2449.3 & 2140.7 & 87.4 \\
\hline France & 2820.7 & 2510.4 & 89.0 \\
\hline Germany & 3254.1 & 3114.9 & 95.7 \\
\hline Hungary & 363.1 & 342.1 & 94.2 \\
\hline Ireland & 103.0 & 93.2 & 90.5 \\
\hline Latvia & 680.7 & 632.3 & 92.9 \\
\hline Lithuania & 544.0 & 515.3 & 94.7 \\
\hline Norway & 1152.0 & 1030.5 & 89.5 \\
\hline Portugal & 188.2 & 167.5 & 89.0 \\
\hline Romania & 2038.1 & 1949.9 & 95.7 \\
\hline Serbia & 305.7 & 272.3 & 89.1 \\
\hline Slovakia & 630.7 & 596.3 & 94.5 \\
\hline Slovenia & 424.0 & 395.1 & 93.2 \\
\hline Spain & 1129.1 & 1007.0 & 89.2 \\
\hline Sweden & 3555.1 & 3427.5 & 96.4 \\
\hline Switzerland & 422.4 & 400.5 & 94.8 \\
\hline
\end{tabular}

Moreover, aspects related to the estimation of broadleaved growing stock should be included.

From an economic viewpoint, the potentially commercial part of the growing stock appears relevant. Denoted as percentage of merchantable stem, this part was calculated as relation between the stem segment from stump height to the top diameter of $7 \mathrm{~cm}$ and the whole stem from ground level up to the stem tip. The merchantable stem part was only defined by the stump height and the minimum diameter. Stem parts below the threshold of $7 \mathrm{~cm}$ were assigned to the stem top. Other important criteria like stem quality or length of assortments were not taken into consideration. Bosela et al. (2016) analysed the status of stem quality assessments by NFIs and found a large diversity in assessed parameters and approaches which require further harmonisation efforts to prepare comparable reporting of stem quality and merchantable assortments.

The reference definition of Cost Action E43 (2010) focuses on the stem volume and indicates an orientation towards

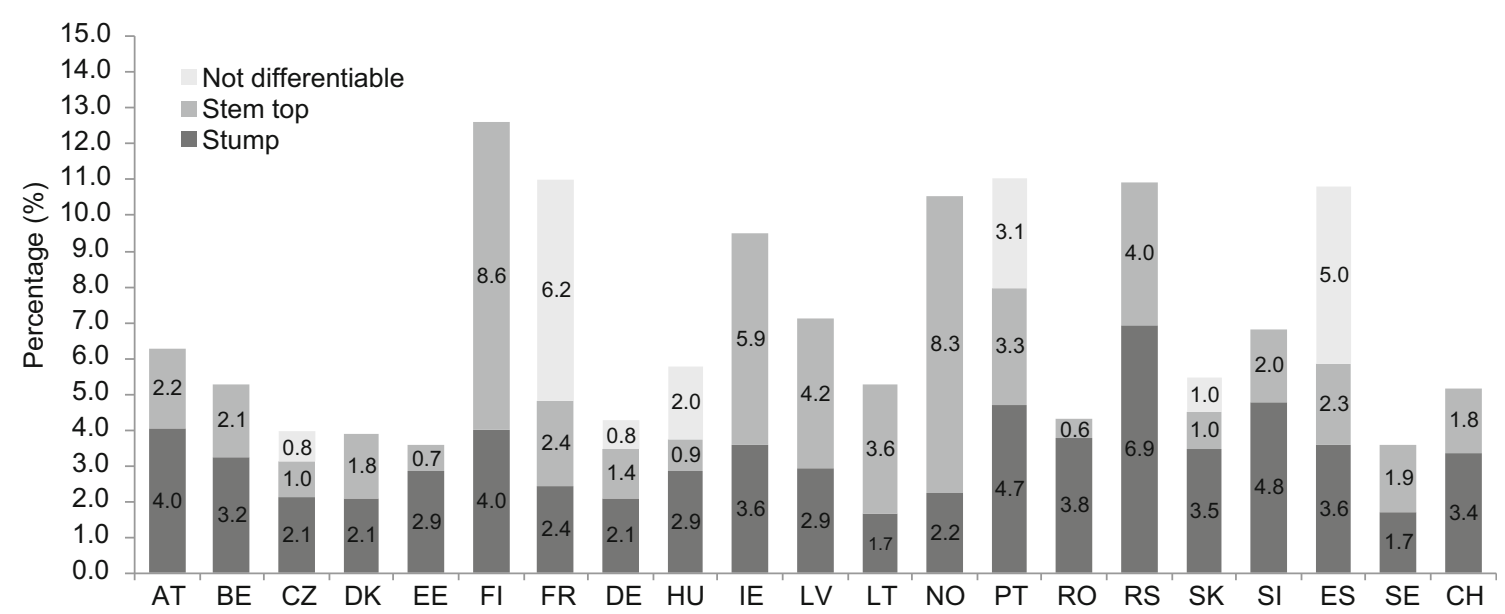

Fig. 4 The percentages of non-merchantable stem differentiated into stump, stem top and a not differentiated part 


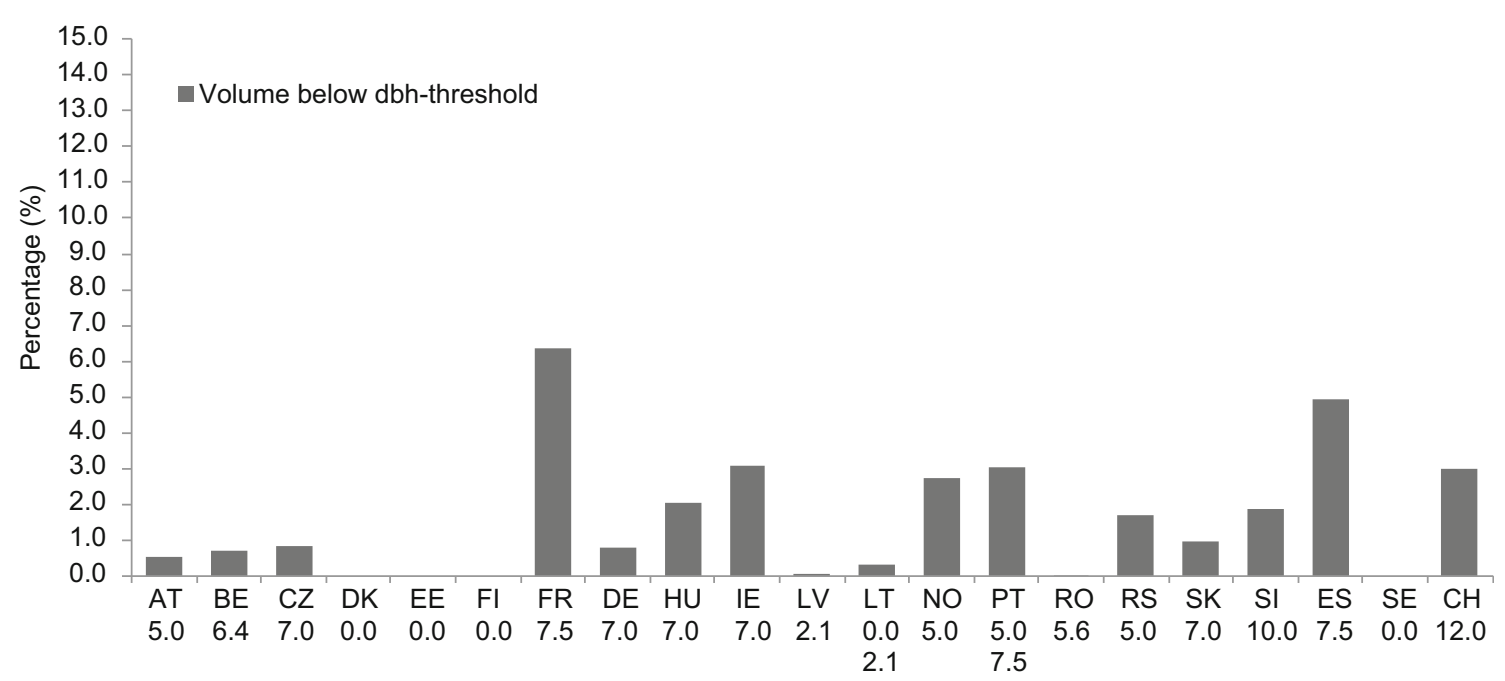

Fig. 5 dbh-thresholds applied by the 21 NFIs and the percentage of stem volume allocated below the dbh-threshold

coniferous trees which usually have a continuous, monopodial stem from the ground until the stem top. For several broadleaved tree species, this concept has limited applicability.

Table 6 Growing stocks of broadleaves for the merchantable stem and the merchantable stem and branches, and the percentages of merchantable branches $(\%)$

\begin{tabular}{|c|c|c|c|}
\hline \multirow[t]{2}{*}{ NFI- country } & \multicolumn{2}{|c|}{ Growing stock (million $\mathrm{m}^{3}$ ) } & \multirow{2}{*}{$\begin{array}{l}\text { Percentage of } \\
\text { merchantable } \\
\text { branches }(\%)\end{array}$} \\
\hline & $\begin{array}{l}\text { Reference } \\
\text { definition } 4 \\
\text { Merchantable } \\
\text { stem }\end{array}$ & $\begin{array}{l}\text { Reference } \\
\text { definition } 5 \\
\text { Merchantable } \\
\text { stem and branches }\end{array}$ & \\
\hline Austria & 212.6 & 244.4 & 13.0 \\
\hline Belgium & 62.9 & 73.6 & 14.5 \\
\hline $\begin{array}{l}\text { Czech } \\
\text { Republic }\end{array}$ & 250.3 & 285.3 & 12.3 \\
\hline Denmark & 56.6 & 64.9 & 12.8 \\
\hline Estonia & 201.1 & - & - \\
\hline Finland & 382.3 & - & - \\
\hline France & 1610.9 & 1842.0 & 12.5 \\
\hline Germany & 988.9 & 1173.1 & 15.7 \\
\hline Hungary & 298.7 & 343.8 & 13.1 \\
\hline Ireland & 14.1 & 17.4 & 18.9 \\
\hline Latvia & 284.4 & 300.0 & 5.2 \\
\hline Lithuania & 211.5 & 218.1 & 3.0 \\
\hline Norway & 243.1 & 250.5 & 3.0 \\
\hline Portugal & 92.6 & 103.1 & 10.1 \\
\hline Romania & 1283.9 & 1450.2 & 11.5 \\
\hline Serbia & 234.9 & 299.0 & 21.4 \\
\hline Slovakia & 349.7 & 389.8 & 10.3 \\
\hline Slovenia & 200.2 & 230.3 & 13.1 \\
\hline Spain & 428.0 & 493.7 & 13.3 \\
\hline Sweden & 623.6 & 649.8 & 4.0 \\
\hline Switzerland & 127.0 & 147.3 & 13.8 \\
\hline
\end{tabular}

Countries with a larger share of broadleaves often include large branches in the growing stock because their wood can be used for similar purposes like stems. Therefore, the percentage of large branches in merchantable tree volume was calculated for broadleaves to evaluate their contribution to growing stock. To correspond with estimates of above-ground biomass, also the volume of small branches would be of interest. Due to the lack of volume models and data, the volume estimation of small branches could not be integrated in this harmonisation work.

\subsection{Comparisons between the growing stock results}

The implementation of stem volume harmonisation by 21 European NFIs has evidenced considerable differences between country-level and harmonised growing stocks. Differences between the country-level growing stocks and the common reference definition of Cost Action E43 (2010) were in the range of -8 to $+32 \%$. Differences of this magnitude indicate the importance of harmonisation when volume estimates are collated from different countries in international statistics (e.g. FAO 2015; FOREST EUROPE 2015). Such unharmonised information can lead to erroneous conclusions in policy and decision-making processes regarding e.g. wood resource availability or forest carbon sequestration.

Considering the individual deviations from the growing stock reference definition, branches have the largest potential to cause a lack in comparability, followed about equally by stumps and stem tops, and concluded by trees below the dbhthreshold. All deviations can contribute relevant amounts of volume and require evaluation when aiming at harmonised volume estimation. According to the presented results, large branches contribute between 3 and $21 \%$ of the merchantable volume of broadleaves. For most NFIs, the share of large branches was in the range of 10 to $15 \%$. The nonmerchantable stem parts consist of stumps and stem tops and 
Fig. 6 Contribution of tree parts to the total above-ground growing stock volume of a) Fagus sylvatica and b) Picea abies a) Fagus sylvatica

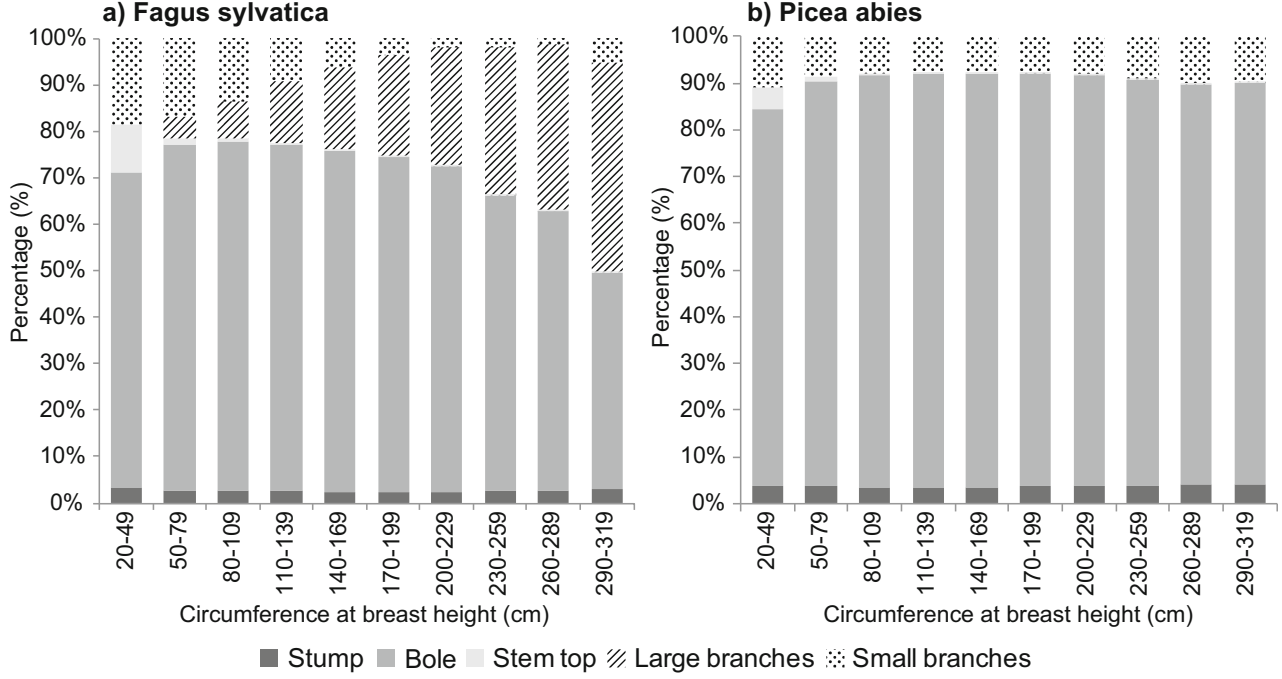

together accounted for 4 to $13 \%$ of the whole stem volume. Stumps contributed between 2 and $7 \%$ and stem tops accounted for 1 to $9 \%$ of the stem volume. The trees below the dbh-threshold represent up to $6 \%$ of stem volume. The volume shares generally correspond to the figures of other studies (e.g. Cienciala et al. 2008; Hladnik and Kobal 2012; Kuliešis and Kulbokas 2009; Mantau et al. 2016) but also depend on the respective forest conditions in the countries.

The results from the 21 NFIs generally represent a broad geographical range within Europe and reflect the differences in tree species composition, tree size distribution and management practices. The percentage of branch volume in broadleaved growing stock differs between Northern Europe and the Baltic region on the one hand, and Western, Southern, Central and Eastern Europe on the other. The largest values are found in Ireland (19\%) and Serbia (21\%) and are due to tree species like beech and oak, a large proportion in larger size-classes, and open-grown trees (Banković et al. 2009; Forest Service 2013). Birch and alder have finer branches than beech and oak and explain the small share of large branches in many northern European countries (3 to 5\%) where these species are the predominant broadleaves. Additionally, the forests in northern countries have a higher proportion of trees in the smaller size-classes which also contribute to a low share of large branches. A large proportion in the smaller size-classes also cause lower percentages of the merchantable stem part. The share of stem top volume thus was higher in Southern, Northern and Western European countries. The influence of the size-class and tree species on the volume share of individual tree parts is illustrated by an example from Belgium in Fig. 6. While large branches contribute a considerable amount of volume for beech, Norway spruce has a negligible amount of large branches. Large and small branches together constitute a much higher volume proportion for beech compared to spruce. Note also that the share of stem top in the lowest sizeclass for Norway spruce is lower than for beech. The share of stumps does not change very much across size-classes. The tree species and size class distribution at country-level have a considerable influence on the magnitude of the individual deviations from the reference definitions.

\section{Conclusions}

The accomplished harmonisation of stem volume estimates essentially contributes to the NFI harmonisation process in Europe. For the first time, comparable growing stocks are available on a large-scale for 21 European NFIs, and the discrepancy between un-harmonised country-level estimates was quantified. The results clearly show the importance of harmonisation for comparable NFI reporting in international statistics. As input for scenario modelling at European level (e.g. Barreiro et al. 2017; Sallnäs et al. 2015), harmonised stem volume estimates are equally important. The implemented stem volume harmonisation allows for estimating various growing stocks as e.g. the whole stem volume, the merchantable part and according to the Cost Action E43 (2010) reference definition, and thus enhanced the flexibility of NFIs in responding to different information needs. The common European NFI estimator (Lanz 2012) was recently developed further under the DIABOLO (2015) project and utilises the harmonised stem volumes to conduct further analyses for various information needs. In connection with the ongoing efforts to harmonise the forest area available for wood supply (Alberdi et al. 2016), the presented work provides the basis for future studies towards harmonised information on wood resources and forest ecosystems of the ENFIN (2018) group for supporting strategic decisions in related policy processes.

Acknowledgements We thank Heimo Matzik for preparing the figures and Ambros Berger for his helpful comments on the manuscript. We also would like to thank the anonymous reviewers for their helpful and constructive suggestions. 
Funding The presented work was conducted as part of the DIABOLO (2015) project. DIABOLO has received funding from the European Union's Horizon 2020 research and innovation programme under grant agreement no. 633464 .

Data availability The implementation of stem volume harmonisation was conducted by the NFIs themselves. No common data set was compiled and therefore cannot be made available. The value of the manuscript is rather the presentation of the implementation and the approaches than the data sources.

\section{Compliance with ethical standards}

Conflict of interest The authors declare that they have no conflicts of interest.

\section{Appendix}

Table 7 Overview about the sampling methods applied by the 21 NFIs

\begin{tabular}{|c|c|c|c|c|c|c|c|c|}
\hline \multirow[t]{2}{*}{ Country-NFI } & \multirow{2}{*}{$\begin{array}{l}\text { NFI cycle used } \\
\text { (years) }\end{array}$} & \multirow{2}{*}{$\begin{array}{l}\text { Grid size } \\
(\mathrm{km} \times \mathrm{km})\end{array}$} & \multirow[t]{2}{*}{ Stratification } & \multirow[t]{2}{*}{ Clustering of plots } & \multirow[t]{2}{*}{ Plot design } & \multicolumn{2}{|c|}{ Small tree sampling } & \multirow{2}{*}{$\begin{array}{l}\text { Plot } \\
\text { number }\end{array}$} \\
\hline & & & & & & Sample plots & Assessments & \\
\hline Austria & 2007-2009 & $3.9 \times 3.9$ & No & $\begin{array}{l}\text { Quadratic cluster with } \\
\text { four plots }\end{array}$ & $\begin{array}{l}\text { Angle count } \\
\text { sampling and } \\
\text { circular plots }\end{array}$ & 1 per cluster & $\begin{array}{l}\text { Stem count, } 2 \\
\text { dbh-classes, species } \\
\text { groups }\end{array}$ & 9905 \\
\hline Belgium & 1994-2008 & $1.0 \times 0.5$ & No & Single plots & $\begin{array}{l}\text { Concentric } \\
\text { circular plots }\end{array}$ & 4 per plot & $\begin{array}{l}\text { Stem count, } 2 \\
\text { dbh-classes }\end{array}$ & 9590 \\
\hline Czech Republic & 2011-2015 & $2.0 \times 2.0$ & No & $\begin{array}{l}\text { Duplex clusters and } \\
\text { single plots }\end{array}$ & $\begin{array}{l}\text { Concentric } \\
\text { circular plots }\end{array}$ & 2 per plot & $\begin{array}{l}\text { Measurement, species, } \\
\mathrm{h}\end{array}$ & 14,521 \\
\hline Denmark & 2012-2016 & $2.0 \times 2.0$ & No & $\begin{array}{l}\text { Quadratic cluster with } \\
\text { four plots }\end{array}$ & $\begin{array}{l}\text { Concentric } \\
\text { circular plots }\end{array}$ & 1 per plot & $\begin{array}{l}\text { Stem count, } 2 \\
\text { dbh-classes }\end{array}$ & 6960 \\
\hline Estonia & 2009-2013 & $5.0 \times 5.0$ & No & $\begin{array}{l}\text { Quadratic clusters with } \\
\text { eight volume plots }\end{array}$ & $\begin{array}{l}\text { Concentric } \\
\text { circular plots }\end{array}$ & 1 per plot & $\begin{array}{l}\text { Stem count, } 1 \\
\text { dbh-class }\end{array}$ & 11,200 \\
\hline Finland & 2009-2013 & $\begin{array}{l}3.0 \times 3.0 \text { to } \\
20.0 \times 20.0\end{array}$ & Yes & $\begin{array}{l}\text { Cluster shape and plot } \\
\text { number depending } \\
\text { on regions }\end{array}$ & $\begin{array}{l}\text { Angle count } \\
\text { sampling }\end{array}$ & 1 per plot & $\begin{array}{l}\text { Measurement, species, } \\
\text { dbh, h }\end{array}$ & 53,601 \\
\hline France & 2009-2013 & $\begin{array}{l}4.5 \times 4.5 \text { to } \\
18.0 \times 18.0\end{array}$ & Yes & Single plots & $\begin{array}{l}\text { Concentric } \\
\text { circular plots }\end{array}$ & $\begin{array}{l}30 \% \text { of year } \\
2010\end{array}$ & $\begin{array}{l}\text { Stem count and } \\
\text { measurement, } 2 \\
\text { dbh-classes, species, } \\
\text { mean height, height }\end{array}$ & 33,004 \\
\hline Germany & 2001-2002 & $\begin{array}{l}2.0 \times 2.0 \text { to } \\
4.0 \times 4.0\end{array}$ & Yes & $\begin{array}{l}\text { Quadratic cluster with } \\
\text { four plots }\end{array}$ & $\begin{array}{l}\text { Angle count } \\
\text { sampling }\end{array}$ & 1 per plot & $\begin{array}{l}\text { Stem count, } 3 \\
\text { dbh-classes }\end{array}$ & 57,053 \\
\hline Hungary & 2010-2014 & $4.0 \times 4.0$ & No & $\begin{array}{l}\text { Quadratic cluster with } \\
\text { four plots }\end{array}$ & $\begin{array}{l}\text { Concentric } \\
\text { circular plots }\end{array}$ & 1 per plot & $\begin{array}{l}\text { Stem count, } 2 \\
\text { height-classes, } \\
\text { species, mean } \\
\text { diameter at half } \\
\text { mean height }\end{array}$ & 5355 \\
\hline Ireland & 2009-2012 & $2.0 \times 2.0$ & No & Single plots & $\begin{array}{l}\text { Concentric } \\
\text { circular plots }\end{array}$ & 1 per plot & $\begin{array}{l}\text { Stem count, species, } \\
\text { height, dbh }\end{array}$ & 1633 \\
\hline Latvia & 2009-2013 & $4.0 \times 4.0$ & No & $\begin{array}{l}\text { Quadratic cluster with } \\
\text { four plots }\end{array}$ & $\begin{array}{l}\text { Concentric } \\
\text { circular plots, } \\
\text { rectangular } \\
\text { plot }\end{array}$ & 1 per plot & $\begin{array}{l}\text { Stem count, species, } \\
\text { mean diameter at } \\
\text { half mean height }\end{array}$ & 8721 \\
\hline Lithuania & 2010-2014 & $\begin{array}{r}2.0 \times 2.0 \text { to } \\
4.0 \times 4.0\end{array}$ & Yes & $\begin{array}{l}\text { Quadratic cluster with } \\
\text { four plots }\end{array}$ & $\begin{array}{l}\text { Concentric } \\
\text { circular plots, } \\
\text { rectangular } \\
\text { plot }\end{array}$ & 1 per plot & $\begin{array}{l}\text { Stem count, } 2 \\
\text { height-classes, mean } \\
\text { height, mean dbh }\end{array}$ & 5259 \\
\hline Norway & 2010-2014 & $\begin{array}{l}3.0 \times 3.0 \\
\quad 3.0 \times 9.0 \\
9.0 \times 9.0\end{array}$ & Yes & Single plots & Circular plots & 4 per plot & $\begin{array}{l}\text { Stem count, } 2 \\
\text { dbh-classes }\end{array}$ & 12,662 \\
\hline Portugal & 2005-2006 & $2.0 \times 2.0$ & No & Single plots & Circular plot & 5 per plot & $\begin{array}{l}\text { Stem count, } 2 \\
\text { dbh-classes, mean } \\
\text { height }\end{array}$ & 5446 \\
\hline Romania & 2008-2012 & $\begin{array}{l}2.0 \times 2.0 \\
\quad \text { and } \\
4.0 \times 4.0\end{array}$ & Yes & $\begin{array}{l}\text { Quadratic cluster with } \\
\text { four plots }\end{array}$ & $\begin{array}{l}\text { Concentric } \\
\text { circular plots }\end{array}$ & 261 plots & Stem count, species & 21,711 \\
\hline Serbia & 2004-2006 & $4.0 \times 4.0$ & No & $\begin{array}{l}\text { Quadratic cluster with } \\
\text { four plots }\end{array}$ & $\begin{array}{l}\text { Concentric } \\
\text { circular plots }\end{array}$ & 1 per plot & Stem count, species & 5631 \\
\hline
\end{tabular}


Table 7 (continued)

\begin{tabular}{|c|c|c|c|c|c|c|c|c|}
\hline \multirow[t]{2}{*}{ Country-NFI } & \multirow{2}{*}{$\begin{array}{l}\text { NFI cycle used } \\
\text { (years) }\end{array}$} & \multirow{2}{*}{$\begin{array}{l}\text { Grid size } \\
(\mathrm{km} \times \mathrm{km})\end{array}$} & \multirow[t]{2}{*}{ Stratification } & \multirow[t]{2}{*}{ Clustering of plots } & \multirow[t]{2}{*}{ Plot design } & \multicolumn{2}{|c|}{ Small tree sampling } & \multirow{2}{*}{$\begin{array}{l}\text { Plot } \\
\text { number }\end{array}$} \\
\hline & & & & & & Sample plots & Assessments & \\
\hline Slovakia & 2005-2006 & $4.0 \times 4.0$ & No & Single plots & $\begin{array}{l}\text { Concentric } \\
\text { circular plots }\end{array}$ & 1 per plot & $\begin{array}{l}\text { Stem count, } 7 \\
\text { dbh-classes, species, } \\
\text { mean height }\end{array}$ & 1419 \\
\hline Slovenia & 2012 & $4.0 \times 4.0$ & No & Single plots & $\begin{array}{l}\text { Concentric } \\
\text { circular plots }\end{array}$ & 1 per plot & Measurement, dbh, h & 760 \\
\hline Spain & 1997-2007 & $1.0 \times 1.0$ & Yes & Single plots & $\begin{array}{l}\text { Concentric } \\
\quad \text { circular plots }\end{array}$ & 1 per plot & $\begin{array}{l}\text { Stem count, } 2 \\
\text { dbh-classes, species, } \\
\text { frequency classes, } \\
\text { mean height }\end{array}$ & 91,922 \\
\hline Sweden & 2011-2015 & $\begin{array}{l}3.0 \times 3.0 \text { to } \\
20.0 \times 20.0\end{array}$ & Yes & $\begin{array}{l}\text { Quadratic or } \\
\text { rectangular clusters } \\
\text { with } 4 \text { to } 12 \text { plots }\end{array}$ & $\begin{array}{l}\text { Concentric } \\
\text { circular plots }\end{array}$ & 2 per plot & $\begin{array}{l}\text { Stem count, } 2 \\
\text { dbh-classes, species, } \\
\text { dbh, h, } \\
\text { height-classes }\end{array}$ & 31,602 \\
\hline Switzerland & 2009-2013 & $1.4 \times 1.4$ & No & Single plots & $\begin{array}{l}\text { Concentric } \\
\text { circular plots }\end{array}$ & 1 per plot & $\begin{array}{l}\text { Stem count, } 12 \\
\quad \text { dbh-classes, species }\end{array}$ & 3695 \\
\hline
\end{tabular}

Table 8 The volume models applied by the 21 European NFIs. $V c_{K}$ tree volume $V$ according to the definition of country $c$ and including the mentioned tree parts $K$, age tree age, $c b h$ circumference at breast height, $d b h$ diameter at breast height, $d b h_{d o m}$ dominant dbh, $d_{g}$ quadratic mean diameter, $d_{03 h}$ upper diameter in $3 / 10$ of the height, $d_{6}$ upper diameter at 6-m height, $d_{7}$ upper diameter at 7-m height, elevation above sea level, forest type even-aged or uneven-aged or intermediate, $h$ tree height, $h_{\text {crown }}$ height to the crown basis, $h_{\text {dom }}$ dominant height, region regions within country, site quality total productivity per hectare and year, social position social rank within the stand, species tree species, tree shape classes of tree form

\begin{tabular}{|c|c|c|c|}
\hline Country-NFI & Volume model & Remark & Reference \\
\hline Austria & 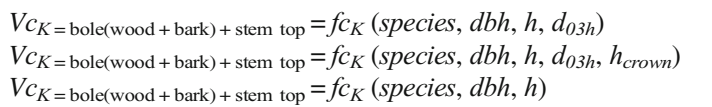 & $\begin{array}{l}\text { Conifers } \\
\text { Broadleaves }\end{array}$ & $\begin{array}{l}\text { Braun (1969); Pollanschütz (1974); } \\
\text { Schieler (1988) }\end{array}$ \\
\hline Belgium & $\begin{array}{l}V c_{K}=\text { bole }(\text { wood }+ \text { bark })=f c_{K}(\text { species }, \text { cbh }, h) \\
V c_{K}=\text { bole }(\text { wood }+ \text { bark })=f c_{K}(\text { species }, \text { cbh }) \\
V c_{K}=\text { bole }(\text { wood }+ \text { bark })=f c_{K}\left(\text { species }, \text { cbh }, h_{\text {dom }}\right)\end{array}$ & & Dagnelie et al. (2013) \\
\hline Czech Republic & $V c_{K}=$ bole $($ wood $)+$ large branches $=f c_{K}($ species $, d b h, h$, age $)$ & & Lesprojekt (1952) \\
\hline Denmark & $\begin{array}{l}V c_{K}=\text { stump + bole }(\text { wood }+ \text { bark })+\text { stem top }=f c_{K}(\text { species }, d b h, h) \\
V c_{K}=\text { stump + bole }(\text { wood }+ \text { bark })+\text { stem top + large branches + small } \\
\text { branches }=f c_{K}\left(\text { species }, d b h, h, d_{g}\right)\end{array}$ & $\begin{array}{l}\text { Conifers } \\
\text { Broadleaves }\end{array}$ & $\begin{array}{l}\text { Madsen (1985); Madsen (1987); } \\
\text { Madsen and Heusèrr (1993); } \\
\text { Tarp-Johansen et al. (1997) }\end{array}$ \\
\hline Estonia & $V c_{K}=$ bole $($ wood + bark $)+$ stem top $=f c_{K}($ species $, d b h, h)$ & & MKJ (2009) \\
\hline Finland & $V c_{K}=$ bole $($ wood + bark $)+$ stem top $=f c_{K}\left(\right.$ species $\left., d b h, h, d_{6}\right)$ & & Lasasenaho $(1976,1982)$ \\
\hline France & $V c_{K}=$ stump + bole $($ wood + bark $)=f c_{K}($ species, cbh,$h)$ & & Morneau and Hervé (2010) \\
\hline Germany & $\begin{array}{l}V c_{K}=\text { stump + bole }(\text { wood + bark })=f c_{K}\left(\text { species }, d b h, h, d_{7}\right) \\
V c_{K}=\text { stump + bole }(\text { wood + bark }) \text { large branches }=f c_{K}\left(\text { species }, d b h, h, d_{7}\right)\end{array}$ & $\begin{array}{l}\text { Conifers } \\
\text { Broadleaves }\end{array}$ & Kublin (2003) \\
\hline Hungary & $V c_{K}=$ bole $($ wood + bark $)+$ large branches $=f c_{K}($ species $, d b h, h)$ & & Sopp and Kolozs (2000) \\
\hline Ireland & $\begin{array}{l}V c_{K}=\text { bole }(\text { wood }+ \text { bark })=f c_{K}(\text { species }, d b h, h) \\
V c_{K}=\text { bole }(\text { wood }+ \text { bark })+\text { large branches }=f c_{K}(\text { species }, d b h, h)\end{array}$ & $\begin{array}{l}\text { Conifers } \\
\text { Broadleaves }\end{array}$ & Riemer et al. (1995) \\
\hline Latvia & $V c_{K}=$ bole $($ wood + bark $)+$ stem top $=f c_{K}($ species $, d b h, h)$ & & Liepa (1996) \\
\hline Lithuania & $V c_{K}=$ stump + bole $($ wood + bark $)+$ stem top $=f c_{K}($ species $, d b h, h)$ & & $\begin{array}{l}\text { Grigaliūnas and Garbinčius (1972); } \\
\text { Kuliešis and Gudas (1989); } \\
\text { Kuliešis and Kenstavičius (1976) }\end{array}$ \\
\hline Norway & $V c_{K}=$ bole $($ wood + bark $)+$ stem top $=f c_{K}($ species $, d b h, h)$ & & $\begin{array}{l}\text { Bauger (1995); Braastad (1966); } \\
\text { Brantseg (1967); } \\
\text { Vestjordet (1967) }\end{array}$ \\
\hline Portugal & $V c_{K}=$ stump + bole $($ wood + bark $)+$ stem top $=f c_{K}($ species $, d b h, h)$ & $\begin{array}{l}\text { Acacia sp., Castanea sativa, } \\
\text { Eucalyptus globulus, } \\
\text { Pinus pinaster, } \\
\text { Pinus pinea, } \\
\text { other conifers }\end{array}$ & $\begin{array}{l}\text { Carvalho (2000); Patrício (2006); } \\
\text { Paulo and Tomé (2006); } \\
\text { Tomé et al. (2007a, b) }\end{array}$ \\
\hline
\end{tabular}


Table 8 (continued)

\begin{tabular}{|c|c|c|c|}
\hline Country-NFI & Volume model & Remark & Reference \\
\hline & $V c_{K}=$ stump + bole $($ wood + bark $)=f c_{K}($ species $, d b h, h)$ & Other oaks, other broadleaves & \\
\hline & $V c_{K}=$ stump + bole $($ wood $)+$ large branches $=f c_{K}($ species,$d b h)$ & Quercus suber & \\
\hline & $V c_{K}=$ stump + bole $($ wood + bark $)+$ large branches $=f c_{K}($ species,$d b h)$ & Quercus ilex s.1. & \\
\hline Romania & $\begin{array}{l}V c_{K}=\text { bole }(\text { wood }+ \text { bark })+\text { stem top }+ \text { large branches }+ \text { small } \\
\quad \text { branches }=f_{C_{K}}(\text { species }, d b h, h)\end{array}$ & & Giurgiu (1974) \\
\hline Serbia & $V c_{K}=$ stump + bole $($ wood + bark $)+$ large branches $=f c_{K}($ species $, d b h, h)$ & & Pantić (1997a, b) \\
\hline Slovakia & $V c_{K}=$ bole(bark $)+$ large branches $=f c_{K}($ species $, d b h, h)$ & & Petráš and Pajtík (1991) \\
\hline Slovenia & $V c_{K}=$ bole $($ wood + bark $)+$ large branches $=f c_{K}($ species,$d b h$, forest type $)$ & & Čokl (1957) \\
\hline Spain & $V c_{K}=$ bole $($ wood + bark $)=f c_{K}($ species $, d b h, h$, tree shape, region $)$ & & ICONA (1990) \\
\hline \multirow[t]{2}{*}{ Sweden } & $V c_{K}=$ bole $($ wood + bark $)+$ stem top $=f_{c_{K}}($ species $, d b h, h)$ & & Andersson (1954); \\
\hline & $V c_{K}=$ bole $($ wood + bark $)+$ stem top $=f c_{K}\left(\right.$ species $\left., d b h, h, h_{\text {crown }}\right)$ & $\begin{array}{l}\text { Alnus glutinosa, } \\
\quad \text { Picea abies, } \\
\text { Pinus sylvestris, Larix sp. }\end{array}$ & $\begin{array}{l}\text { Braastad (1967); } \\
\text { Eriksson (1973); } \\
\text { Hagberg and Matérn (1975); } \\
\text { Näslund and Hagberg (1950) }\end{array}$ \\
\hline \multirow[t]{2}{*}{ Switzerland } & $V c_{K}=$ stump + bole $($ wood + bark $)+$ stem top $=f_{c_{K}}\left(\right.$ species $\left., d b h, h, d_{7}\right)$ & Volume function & Kaufmann (2001) \\
\hline & $\begin{array}{l}V c_{K}=\text { stump }+ \text { bole }(\text { wood }+ \text { bark })+\text { stem top }=f c_{K}\left(\text { species }, d b h, d b h_{\text {dom }},\right. \\
\text { bifurcation, social position, elevation, site quality })\end{array}$ & Tariff function & \\
\hline
\end{tabular}

Table 9 Definitions for common reporting of European NFIs

\begin{tabular}{|c|c|c|}
\hline Term & & Definition \\
\hline \multirow[t]{2}{*}{ Volumes } & Growing stock & $\begin{array}{l}\text { Growing stock is the above-ground volume of living and standing stems above stump over a } \\
\text { specified area. Included is the stem volume from the stump height up to and including the stem } \\
\text { top and the bark. Branches are excluded }\end{array}$ \\
\hline & $\begin{array}{l}\text { Volume of living stems } \\
\text { above stump }\end{array}$ & $\begin{array}{l}\text { The volume of living stems above stump is the aggregated above-ground volume of all living and } \\
\text { standing stems, over a specified land area. Included are over-bark stem volumes-from the stump } \\
\text { height to and including the stem top-of living stems with a diameter at breast height of more } \\
\text { than } 0 \mathrm{~cm} \text { (height of more than } 1.30 \mathrm{~m} \text { ). Branches are excluded }\end{array}$ \\
\hline \multirow[t]{2}{*}{ Tree characteristics } & Living tree & A living tree is a tree having a stem with an active or a dormant cambium \\
\hline & Lying tree & A lying tree is a tree whose main stem is in the majority of its length lying on the ground \\
\hline \multirow[t]{7}{*}{ Tree parts } & Large branches & $\begin{array}{l}\text { The large branches of a tree are the portion of the above-ground lateral parts with a diameter of more } \\
\text { than or equal to the defined diameter threshold }\end{array}$ \\
\hline & Small branches & $\begin{array}{l}\text { The small branches of a tree are the portion of the above-ground lateral parts with a diameter of less } \\
\text { than the defined diameter threshold }\end{array}$ \\
\hline & Stem & The stem of a tree is the above-ground part of the main (off) shoot with apical dominance \\
\hline & Stem top & $\begin{array}{l}\text { The stem top of a tree is the topmost part of the stem from an over-bark base-diameter of the defined } \\
\text { diameter threshold to the stem tip }\end{array}$ \\
\hline & Bole & The bole of a tree is the above-ground part of the stem between stump and the stem top \\
\hline & Stump & $\begin{array}{l}\text { The stump of a tree is the above-ground base part of the stem which would remain after a tree was } \\
\text { cut under normal felling practices }\end{array}$ \\
\hline & Bark & $\begin{array}{l}\text { The bark of a tree includes all tissues of the main stem, lateral parts and below-ground parts between } \\
\text { the xylem and the epidermis of the phellem }\end{array}$ \\
\hline
\end{tabular}

From Gschwantner et al. (2009) and Lanz et al. (2010) 
Table 10 Bridging functions for harmonising the stem volume estimates. $V r_{K}$ sample tree volume according to the reference definitions including the tree parts $K, V r_{k}$ volume of tree part $k$ according to the reference definitions, age tree age, altitude height above sea level, $b d_{v c}$ bark density of virgin cork, $c b h$ circumference at breast height, $c r$ crown ratio, $d b h$ diameter at breast height, $d b h_{d o m}$ dominant dbh, $d_{g}$ quadratic mean diameter, $d_{h=x}$ diameter at a specified height $x, d_{\text {stem top }}$ base diameter of the stem top, $d_{\text {stump }}$ diameter at stump height, $d_{\text {stump base }}$ diameter at the stump base, $d_{t l}$ top diameter limit, $d_{u}$ debarking diameter, $d_{03 h}$ upper diameter in $3 / 10$ of the height, $d_{6}$ upper diameter in $6 \mathrm{~m}$ height, $d_{7}$ upper diameter in $7 \mathrm{~m}$ height, forest type even-aged or uneven-aged or intermediate, $h$ tree height, $h_{k}$ height to the crown basis, $h_{\text {dom }}$ dominant height, $h_{d=7 \mathrm{~cm}}$ height where the diameter is $7 \mathrm{~cm}, h_{\text {stump }}$

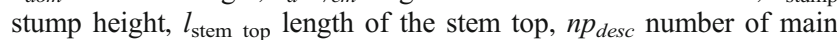
debarking branches, region regions within country, slope slope of the terrain, species tree species

$\mathrm{NFI}$ - country Bridging function

Reference/origin

Volume model

\begin{tabular}{|c|c|c|c|c|}
\hline & Approach & & & \\
\hline \multirow[t]{4}{*}{ Austria } & \multirow[t]{3}{*}{ Tree part } & Stump & Alternative & Empirical \\
\hline & & Stem top & Complementary & Empirical \\
\hline & & Branches & Complementary & Empirical \\
\hline & dbh-threshold & & Complementary & Empirical \\
\hline \multirow[t]{4}{*}{ Belgium } & \multirow[t]{3}{*}{ Tree part } & Stump & Taper curve & $\begin{array}{l}\text { Empirical, } \\
\text { geometric }\end{array}$ \\
\hline & & Stem top & Taper curve & $\begin{array}{l}\text { Empirical, } \\
\text { geometric }\end{array}$ \\
\hline & & Branches & Complementary & Empirical \\
\hline & dbh-threshold & & Complementary & Geometric \\
\hline \multirow{5}{*}{$\begin{array}{l}\text { Czech } \\
\text { Republic }\end{array}$} & \multirow[t]{4}{*}{ Tree part } & Stump & Complementary & Empirical \\
\hline & & Stem top & Complementary & Empirical \\
\hline & & Branches & Complementary & Empirical \\
\hline & & Bark & Alternative & Empirical \\
\hline & dbh-threshold & & Complementary & Empirical \\
\hline Denmark & Tree part & Stump & Complementary & Empirical \\
\hline
\end{tabular}

$\begin{array}{cc}V r_{K=\text { stump }+ \text { bole }+ \text { stem }} & \text { Braun (1969); } \\ \text { top }=f r_{K}(\text { species }, d b h, h), & \text { Pollanschütz (1974), } \\ V r_{K=\text { stump + bole + stem }} & \text { re-parameterisation }\end{array}$

= stump + bole + stem $\left.d_{03 h}, h, h_{k}\right)$

$V r_{k=\text { stem top }} / V r_{K=\text { stump + bole + stem }}$ top $=f r_{k}($ species $, d b h, h)$

$V r_{k=\text { large branches }}=f r_{k}$ (species, $\left.d b h\right), \quad$ Gschwantner and $V r_{k=\text { large branches }}=f r_{k}$ (species, $\left.d b h, c r\right) \quad$ Schadauer (2006),

$V r_{K=\text { stem }}=f r_{K}($ species,$d b h), \quad$ Newly developed $V r_{K=\text { stem }} / \mathrm{ha}=f r_{K}($ species, coverage) $d_{\text {stump }}=f($ species $, c b h, h)$,

$V r_{k=\text { stump }}=f r\left(d_{\text {stump }}, h_{\text {stump }}\right)$

$h_{d=7 \mathrm{~cm}}=f($ species, $c b h, h), V r_{k=\text { stem }} \quad$ Dagnelie et al. (2013) top $=f r_{k}\left(d_{\text {stem top }}, l_{\text {stem top }}\right)$

$V r_{k=\text { large branches }}=f r_{k}($ species,$d b h) \quad$ Dagnelie et al. (2013)

$V r_{K=\text { stem }}=f r_{K}(d b h, h)$,

$V r_{k=\text { stem top }}=f r_{k}(d b h, h)$

$V r_{k=\text { stump }} / V r_{K=\text { bole }+ \text { large }}$

branches $=f r_{k}($ species,$d b h)$

$V r_{k=\text { stem top }} / V r_{K=\text { bole }+ \text { large }}$

branches $=f r_{k}($ species, $d b h)$

$V r_{\mathrm{k}=\text { large branches }} / V r_{K=\text { bole }+ \text { large }}$

branches $=f r_{k}($ species, $d b h)$

$V r_{K}=$ bole + large branches $=f r_{K}$ (species, $d b h, h$, age $)$

$V r_{K=\text { stem }}=f r_{K}($ species,$h)$

$V r_{K=\text { bole }+ \text { large }}$ branches $=f r_{K}$ (species, $\left.d b h, h, d_{g}, d_{t l}\right)$, $V r_{k=\text { stump }} / V r_{K=\text { bole }+ \text { large }}$ branches $=f r_{k}($ species,$d b h)$

Stem top Taper curve Empirical

$V r_{K=\text { bole }+ \text { large }}$ branches $=f r_{K}\left(\right.$ species $\left., d b h, h, d_{g}, d_{t l}\right)$, $V r_{k=\text { stem top }} / V r_{K=\text { bole }+ \text { large }}$ branches $=f r_{k}($ species,$d b h)$

Branches Complementary Empirical

$\begin{array}{lllll}\text { Estonia } & \text { Tree part } & \begin{array}{l}\text { Stump } \\ \text { Stem top }\end{array} & \begin{array}{l}\text { Taper curve } \\ \text { Taper curve }\end{array} & \begin{array}{l}\text { Empirical } \\ \text { Empirical }\end{array} \\ & & \begin{array}{l}\text { Branches } \\ \text { Finland }\end{array} & \text { not calculated } & \\ & \text { Tree part } & \text { Stump } & \text { Taper curve } & \text { Empirical }\end{array}$

Stem top Taper curve Empirical

Branches not calculated

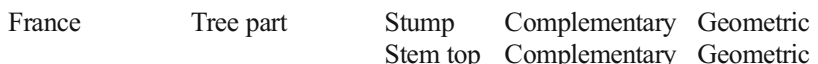

$V r_{k=\text { large branches }} / V r_{K=\text { bole }+ \text { large }}$ branches $=f r_{k}($ species,$d b h)$

$V r_{k=\text { stump }}=f r_{k}\left(\right.$ species $\left., d b h, h, h_{\text {stump }}\right)$

$V r_{k=\text { stem top }}=f r_{k}$ (species, $d b h, h$, $h_{d=7 \mathrm{~cm})}$

$V r_{K}=$ stump + bole + stem top $=f r_{K}$ (species, $\left.d b h, h, d_{6}\right)$, $V r_{K=\text { bole }+ \text { stem top }}=f r_{K}$ (species, $d b h$, $\left.h, d_{6}\right), V r_{K=\text { stump + bole + stem top }}$ $V r_{K}=$ bole + stem top $=f r_{K}$ (species)

$V r_{K}=$ bole + stem top $=f r_{K}$ (species, $d b h$, $\left.h, d_{6}\right), V r_{K=\text { bole }}=f r_{K}$ (species, $d b h$, $\left.h, d_{6}\right), V r_{K=\text { bole }+ \text { stem }}$ top $/ V r_{k=\text { bole }}=f r_{K}($ species $, d b h, h)$

$V r_{k=\text { stump }}=f r_{k}\left(d b h, h, h_{\text {stump }}\right)$ $V r_{k=\text { stem top }}=f r_{k}\left(d_{\text {stem top }}, l_{\text {stem top }}\right)$
Belgium

Parez et al. (1990)

Parez et al. (1990)

Parez et al. (1990)

Lesprojekt (1952)

Konôpka et al. (2010), re-parameterisation, Slovakia Madsen (1985); Madsen (1987); Madsen and Heusèrr (1993); Tarp-Johansen et al. (1997); Parez et al. (1990), Czech Republic Madsen (1985); Madsen (1987);

Madsen and Heusèrr (1993);

Tarp-Johansen et al. (1997); Parez et al. (1990), Czech Republic Parez et al. (1990), Czech Republic

Ozolins (2002)

Ozolins (2002)

Laasasenaho (1982)

Laasasenaho (1982)

Newly developed Newly developed 
Table 10 (continued)

NFI-country Bridging function

Reference/origin

\begin{tabular}{|c|c|c|c|c|c|c|}
\hline & Approach & & & & Volume model & \\
\hline & & Branches & Alternative & Empirical & $\begin{array}{l}V r_{K=\text { stump }}+\text { bole }+ \text { large } \\
\quad \text { branches }=f r_{K}(\text { species }, c b h, h)\end{array}$ & $\begin{array}{l}\text { C. Deleuze, personal } \\
\text { communication, dataset } \\
\text { (EMERGE) }\end{array}$ \\
\hline & dbh-threshold & & Complementary & $\begin{array}{l}\text { Geometric, } \\
\text { empirical }\end{array}$ & $\begin{array}{l}V r_{K=\text { stem }}=f r_{K}(d b h, h), \\
V r_{K=\text { stem }} / \text { ha }=f r_{K}\left(V c_{K} / h_{\text {plot }},\right. \\
\text { species, coverage, humus, } \\
\text { topography) }\end{array}$ & Newly developed \\
\hline \multirow[t]{4}{*}{ Germany } & Tree part & Stump & Complementary & Empirical & $\begin{array}{l}V r_{k=\text { stump }} / V r_{K=\text { bole }+ \text { large }} \\
\quad \text { branches } \\
=f r_{k}(\text { species }, d b h)\end{array}$ & Parez et al. (1990), Czech Republic \\
\hline & & Stem top & Complementary & Empirical & $\begin{array}{l}V r_{k=\text { stem top }} / V r_{K}=\text { stump }+ \text { bole }+ \text { stem } \\
\text { top }=f r_{k}(\text { species }, d b h, h)\end{array}$ & Newly developed, Austria \\
\hline & & Branches & Complementary & Empirical & $\begin{array}{l}\mathrm{V}_{k=\text { large branches }}=f r_{k}(\text { species } \\
\quad d b h, \text { altitude })\end{array}$ & Kaufmann (2001), Switzerland \\
\hline & dbh-threshold & & Complementary & Empirical & $V r_{K=\text { stem }}=f r_{K}($ species,$d b h)$ & Newly developed, Austria \\
\hline \multirow[t]{4}{*}{ Hungary } & Tree part & Stump & Complementary & $\begin{array}{l}\text { Empirical, } \\
\text { geometric }\end{array}$ & $\begin{aligned} d_{\text {stump }} & =f(\text { species }, d b h), \\
V r_{k} & =\text { stump } \\
= & f r_{k}\left(d_{\text {stump }}, h_{\text {stump }}\right)\end{aligned}$ & Hungary \\
\hline & & Stem top & Complementary & Empirical & $\begin{array}{l}V r_{k=\text { stem top }} / V r_{K} \text { stump }+ \text { bole }+ \\
\quad \text { stem top }=f r_{k}(\text { species }, d b h)\end{array}$ & Newly developed, Austria \\
\hline & & Branches & Complementary & Empirical & $V r_{k=\text { large branches }}=f r_{k}($ species,$d b h)$ & $\begin{array}{l}\text { Gschwantner and Schadauer (2006), } \\
\text { re-parameterisation, Austria }\end{array}$ \\
\hline & dbh-threshold & & Complementary & Geometric & $V r_{K=\text { stem }}=f r_{K}\left(d_{h / 2}, h_{\text {mean }}\right)$ & Hungary \\
\hline \multirow[t]{4}{*}{ Ireland } & Tree part & Stump & Taper curve & Empirical & $\begin{array}{l}V r_{k=\text { stump }}=f r_{k}(\text { species }, d b h, \\
\left.\quad h, d_{h=x}\right)\end{array}$ & Riemer et al. (1995) \\
\hline & & Stem top & Taper curve & Empirical & $V r_{k=\text { stem top }}=f r_{k}\left(\right.$ species $\left., d b h, h, d_{h=\mathrm{x}}\right)$ & Riemer et al. (1995) \\
\hline & & Branches & Complementary & Empirical & $\begin{array}{l}V r_{k=\text { large branches }}=f r_{k}(\text { species } \\
\quad d b h, c r)\end{array}$ & $\begin{array}{l}\text { Gschwantner and Schadauer (2006), } \\
\text { re-parameterisation, Austria }\end{array}$ \\
\hline & dbh-threshold & & Complementary & Empirical & $\begin{array}{l}V r_{K=\text { stem }}=f r_{K}\left(\text { species }, d b h, h, d_{h=x}\right) \\
V r_{K=\text { stem top }}=f r_{K}(\text { species }, d b h, \\
\left.h, d_{h=x}\right)\end{array}$ & $\begin{array}{l}\text { Riemer et al. (1995), } \\
\text { re-parameterisation }\end{array}$ \\
\hline \multirow[t]{4}{*}{ Latvia } & Tree part & Stump & Complementary & $\begin{array}{l}\text { Empirical, } \\
\text { geometric }\end{array}$ & $\begin{array}{l}d_{\text {stump }}=f(\text { species }, d b h, h) \\
\quad d_{\text {stumpbase }}=f(\text { species }, d b h) \\
V r_{k=\text { stump }}=f r_{k}\left(d_{\text {stump }}, d_{\text {stumpbase }}\right. \\
\left.h_{\text {stump }}\right)\end{array}$ & Ozolins (2002), Newly developed \\
\hline & & Stem top & Complementary & $\begin{array}{l}\text { Empirical, } \\
\text { geometric }\end{array}$ & $\begin{array}{l}l_{\text {stem top }}=f(d b h, h) \\
\quad V r_{k=\text { stem top }}=f r_{k}\left(d_{\text {stem top }}, l_{\text {stem top }}\right)\end{array}$ & Newly developed \\
\hline & & Branches & Complementary & Empirical & $V r_{k=\text { large branches }}=f r_{k}($ species,$d b h)$ & Dagnelie et al. (2013), Belgium \\
\hline & dbh-threshold & & Complementary & Geometric & $V r_{K=\text { stem }}=f r_{K}\left(d_{h / 2}, h_{\text {mean }}\right)$ & Latvia \\
\hline \multirow[t]{4}{*}{ Lithuania } & Tree part & Stump & Complementary & Empirical & $V r_{k=\text { stump }}=f r_{k}($ species,$d b h)$ & Kuliešis and Kulbokas (2009) \\
\hline & & Stem top & Complementary & Empirical & $V r_{k=\text { stem top }}=f r_{k}($ species,$d b h)$ & Kuliešis and Kulbokas (2009) \\
\hline & & Branches & Complementary & Empirical & $V r_{k=\text { large branches }}=f r_{k}($ species,$d b h)$ & Newly developed \\
\hline & dbh-threshold & & Complementary & Empirical & $V r_{K=\text { stem }}=f r_{K}(d b h)$ & Lithuania \\
\hline \multirow[t]{4}{*}{ Norway } & Tree part & Stump & Complementary & $\begin{array}{l}\text { Empirical, } \\
\text { geometric }\end{array}$ & $\begin{array}{c}d_{\text {stump }}=f(d b h), V r_{k=\text { stump }}=f r_{k}\left(d_{\text {stump }},\right. \\
\left.h_{\text {stump }}\right)\end{array}$ & Norway \\
\hline & & Stem top & Complementary & Empirical & $V r_{k=\text { stemtop }}=f r_{k}($ species $, d b h, h)$ & $\begin{array}{l}\text { Spruce and pine: Vestjordet (1967), } \\
\text { Birch: newly developed, Finland }\end{array}$ \\
\hline & & Branches & Complementary & Empirical & $V r_{k=\text { large branches }}=f r_{k}($ species,$d b h)$ & Dagnelie et al. (2013), Belgium \\
\hline & dbh-threshold & & Complementary & Empirical & $V r_{K=\text { stem }}=f r_{K}(d b h)$ & Jonson (1928) \\
\hline \multirow[t]{5}{*}{ Portugal } & Tree part & Stump & Complementary & $\begin{array}{l}\text { Empirical, } \\
\text { geometric }\end{array}$ & $\begin{aligned} d_{\text {stump }} & =f(\text { species }, d b h) \\
V r_{k} & =\text { stump } \\
= & f r_{k}\left(d_{\text {stump }}, h_{\text {stump }}\right)\end{aligned}$ & Riemer et al. (1995), Ireland \\
\hline & & Stem top & Complementary & Geometric & $V r_{k=\text { stem top }}=f r_{k}\left(d_{\text {stemtop }}, l_{\text {stemtop }}\right)$ & Portugal \\
\hline & & Branches & Complementary & Empirical & $V r_{k=\text { large branches }}=f r_{k}($ species,$d b h)$ & IFN2 (1986-1995), Spain \\
\hline & & Bark & Complementary & Empirical & $\begin{array}{l}V r_{k=\text { virgin cork }}=f r_{k}\left(\text { species, } d_{u}, \mathrm{np}_{\mathrm{desc}},\right. \\
\left.\quad b d_{v c}\right)\end{array}$ & Only cork oak: newly developed \\
\hline & dbh-threshold & & Complementary & Empirical & $\begin{array}{l}V r_{K=\text { stem }}=f r_{K}(d b h, h) \\
\quad V r_{K=\text { stem }}=f r_{K}\left(\text { species }, d_{u}, \text { wd }\right)\end{array}$ & $\begin{array}{l}\text { AFN (2010), cork oak: newly } \\
\text { developed }\end{array}$ \\
\hline \multirow[t]{4}{*}{ Romania } & Tree part & Stump & Complementary & Empirical & $V r_{k=\text { stump }}=f r_{k}\left(\right.$ species $\left., d b h, h, h_{\text {stump }}\right)$ & Newly developed, Austria \\
\hline & & Stem top & Complementary & Empirical & $V r_{k=\text { stem top }}=f r_{k}($ species $, d b h, h)$ & Newly developed, Austria \\
\hline & & Branches & Complementary & Empirical & $V r_{k=}$ large branches $=f r_{k}($ species,$d b h)$ & $\begin{array}{l}\text { Parez et al. (1990); Gschwantner and } \\
\text { Schadauer (2006), } \\
\text { re-parameterisation, Austria }\end{array}$ \\
\hline & dbh-threshold & & Complementary & Empirical & $V r_{K=\text { stem }} / \mathrm{ha}=f r_{K}\left(V c_{K} /\right.$ ha $a_{\text {plot }}$, species $)$ & Romania \\
\hline \multirow[t]{2}{*}{ Serbia } & Tree part & Stump & Complementary & Empirical & $V r_{k=\text { stump }}=f r_{k}\left(\right.$ species $\left., d b h, h_{\text {stump }}\right)$ & Newly developed, Austria \\
\hline & & Stem top & Complementary & Empirical & $V r_{k=\text { stem top }}=f r_{k}($ species,$d b h)$ & Newly developed, Austria \\
\hline
\end{tabular}


Table 10 (continued)

NFI-country Bridging function

Reference/origin

\begin{tabular}{ll}
\hline Approach & Volume model
\end{tabular}

\begin{tabular}{|c|c|c|c|c|c|c|}
\hline & & Branches & Complementary & Empirical & $V r_{k=\text { large branches }}=f r_{k}($ species,$d b h)$ & $\begin{array}{l}\text { Gschwantner and Schadauer (2006), } \\
\text { re-parameterisation, Austria }\end{array}$ \\
\hline & dbh-threshold & & Complementary & Geometric & $V r_{K=\text { stem }}=f r_{K}(d b h, h)$ & Serbia \\
\hline \multirow[t]{5}{*}{ Slovakia } & \multirow[t]{4}{*}{ Tree part } & Stump & Complementary & Empirical & $\begin{array}{l}V r_{K}=\text { stump }+ \text { bole }+ \text { stem top } / V r_{K}=\text { bole }+ \text { stem } \\
\quad \text { top }=f r_{k}(d b h, \text { slope })\end{array}$ & Newly developed, Austria \\
\hline & & Stem top & Alternative & Empirical & $V r_{K=\text { bole }+ \text { stem top }}=f r_{K}($ species $, d b h, h)$ & Petráš and Pajtík (1991) \\
\hline & & Branches & Alternative & Empirical & $\begin{array}{l}V r_{K}=\text { bole }+ \text { large } \\
\quad \text { branches }=f r_{K}(\text { species }, d b h, h)\end{array}$ & Petráš and Pajtík (1991) \\
\hline & & Bark & Alternative & Empirical & $\begin{array}{l}V r_{K}=\text { bole }+ \text { large } \\
\quad \text { branches }=f r_{K}(\text { species }, d b h, h)\end{array}$ & Petráš and Pajtík (1991) \\
\hline & dbh-threshold & & Complementary & Empirical & $V r_{K=\text { stem }}=f r_{K}($ species,$h)$ & $\begin{array}{l}\text { Konôpka et al. (2010), } \\
\text { re-paramerisation }\end{array}$ \\
\hline \multirow[t]{4}{*}{ Slovenia } & \multirow[t]{3}{*}{ Tree part } & Stump & Complementary & Empirical & $V r_{k=\text { stump }}=f r_{k}\left(\right.$ species $\left., d b h, h_{\text {stump }}\right)$ & Newly developed, Austria \\
\hline & & Stem top & Complementary & Empirical & $V r_{k=\text { stemtop }}=f r_{k}($ species,$d b h)$ & Newly developed, Austria \\
\hline & & Branches & Complementary & Empirical & $V r_{k=\text { large branches }}=f r_{k}($ species,$d b h)$ & $\begin{array}{l}\text { Gschwantner and Schadauer (2006), } \\
\text { re-parameterisation, Austria }\end{array}$ \\
\hline & dbh-threshold & & Complementary & Geometric & $\begin{array}{l}V r_{K=\text { stem }}=f r_{K}(d b h, h) \\
\quad V r_{k=\text { stemtop }}=f r_{k}(\text { species }, d b h, h)\end{array}$ & Slovenia; newly developed, Austria \\
\hline \multirow[t]{4}{*}{ Spain } & \multirow[t]{2}{*}{ Tree part } & Stump & Complementary & $\begin{array}{l}\text { Empirical, } \\
\text { geometric }\end{array}$ & $\begin{aligned} d_{\text {stump }} & =f(d b h, h) \\
V & =f r_{k}=\text { stump } \\
= & f r_{k}\left(d_{\text {stump }}, h_{\text {stump }}\right)\end{aligned}$ & Spain \\
\hline & & Stem top & Complementary & $\begin{array}{l}\text { Empirical, } \\
\text { geometric }\end{array}$ & $\begin{array}{l}l_{\text {stem top }}=f(d b h, h) \\
\quad V r_{k=\text { stem top }}=f r_{k}\left(d_{\text {stem top }}, l_{\text {stem top }}\right)\end{array}$ & Spain \\
\hline & \multirow{5}{*}{$\begin{array}{l}\text { dbh-threshold } \\
\text { Tree part }\end{array}$} & Branches & Complementary & Empirical & $V r_{k=1}$ large branches $=f r_{k}($ species,$d b h)$ & IFN2 (1986-1995) \\
\hline & & & Complementary & Empirical & $V r_{K=\text { stem }}=f r_{K}($ species,$d b h)$ & Newly developed, Austria \\
\hline \multirow[t]{3}{*}{ Sweden } & & Stump & Complementary & Empirical & $V r_{k=\text { stump }}=f r_{k}\left(\right.$ species $\left., d b h, h_{\text {stump }}\right)$ & $\begin{array}{l}\text { Marklund (1988); Petersson and } \\
\text { Ståhl (2006) }\end{array}$ \\
\hline & & Stem top & Complementary & Empirical & $V r_{k=\text { stem top }}=f r_{k}($ species,$d b h)$ & $\begin{array}{l}\text { Marklund (1988); } \\
\quad \text { Petersson and Ståhl (2006) }\end{array}$ \\
\hline & & Branches & Complementary & Empirical & $V r_{k=\text { large branches }}=f r_{k}($ species,$d b h)$ & $\begin{array}{l}\text { Marklund (1988); } \\
\quad \text { Petersson and Ståhl (2006) }\end{array}$ \\
\hline \multirow[t]{4}{*}{ Switzerland } & \multirow[t]{3}{*}{ Tree part } & Stump & Taper curve & $\begin{array}{l}\text { Empirical, } \\
\text { geometric }\end{array}$ & $\begin{array}{c}V r_{k=\text { stump }}=f r_{k}\left(\text { species }, d b h, h, d_{7}\right) \\
\quad V r_{k=\text { stump }}=f r_{k}\left(d_{\text {stump }}, h_{\text {stump }}\right)\end{array}$ & Kaufmann (2001) \\
\hline & & Stem top & Taper curve & $\begin{array}{l}\text { Empirical, } \\
\text { geometric }\end{array}$ & $\begin{array}{l}V r_{k=\text { stem top }}=f r_{k}\left(\text { species }, d b h, h, d_{7}\right) \\
\quad V r_{k=\text { stem top }}=f r_{k}\left(d_{\text {stem top }}, l_{\text {stem top }}\right)\end{array}$ & Kaufmann (2001) \\
\hline & & Branches & Complementary & Empirical & $\begin{array}{l}V r_{k}=\text { large branches }=f r_{k}(\text { species }, d b h, \\
\quad \text { altitude, region })\end{array}$ & Kaufmann (2001) \\
\hline & dbh-threshold & & Complementary & Empirical & $\begin{array}{l}V r_{K=\text { stem }}=f r_{K}(\text { species }, d b h), \\
\quad V r_{k=\text { stemtop }}=f r_{k}(\text { species }, d b h)\end{array}$ & Newly developed, Austria \\
\hline
\end{tabular}


Open Access This article is distributed under the terms of the Creative Commons Attribution 4.0 International License (http:// creativecommons.org/licenses/by/4.0/), which permits unrestricted use, distribution, and reproduction in any medium, provided you give appropriate credit to the original author(s) and the source, provide a link to the Creative Commons license, and indicate if changes were made.

Publisher's note Springer Nature remains neutral with regard to jurisdictional claims in published maps and institutional affiliations.

\section{References}

AFN (2010) Inventário Florestal Nacional, Portugal Continental - IFN5 2005-2006. Relatório Final. Autoridade Florestal Nacional, Lisboa $209 \mathrm{p}$

Alberdi I, Michalak R, Fischer C, Gasparini P, Brändli UB, Tomter SM, Kuliesis A, Snorrason A, Redmond J, Hernández L, Lanz A, Vidondo B, Stoyanov N, Stoyanova M, Vestman M, Barreiro S, Marin G, Cañellas I, Vidal C (2016) Towards harmonized assessment of European forest availability for wood supply in Europe. Forest Policy Econ 70:20-29. https://doi.org/10.1016/j.forpol.2016.05.014

Andersson S-O (1954) Funktioner och tabeller för kubering av småträd. Medd från Statens Skogsforskningsinstitut 44(12): $29 \mathrm{p}$

Banković S, Medarević M, Pantić D, Petrović N (2009) The National Forest Inventory of the republic of Serbia: the growing stock of the republic of Serbia. Monograph, Ministry of Agriculture, Forestry and Water Management of the Republic of Serbia, Forest Directorate, Belgrade $238 \mathrm{p}$

Barreiro S, Schelhaas M-J, McRoberts RE, Kändler G (2017) Forest inventory-based projection Systems for Wood and Biomass Availability. Springer, Cham. 330 p. https://doi.org/10.1007/978-3319-56201-8

Bauger E (1995) Funksjoner og tabeller for kubering av stående trær. Furu, gran og sitkagran på Vestlandet. Rapport fra Skogforsk 16/ 95. $26 \mathrm{p}$

Bosela M, Redmond J, Kucera M, Marin G, Adolt R, Gschwantner T, Petras R, Korhonen KT, Kuliesis A, Kulbokas G, Fischer C, Lanz A (2016) Stem quality assessment in European National Forest Inventories: an opportunity for harmonised reporting? Ann For Sci 73:635-648. https://doi.org/10.1007/s13595-015-0503-8

Braastad H (1966) Volumtabeller for bjørk. Medd nor Skogforsok 21:2378

Braastad H (1967) Produksjonstabeller for bjørk. Medd nor Skogforsok 22:265-365

Brantseg A (1967) Furu sønnafjells. Kubering av stående skog Funksjoner og tabeller. Medd nor Skogforsok 22:689-739

Braun R (1969) Österreichische Forstinventur - Methodik der Auswertung und Standardfehlerberechnung. Mitt Forstl Bundesvers Anst Wien 84:60 p

Carvalho J (2000) Crescimento. Produção e Ecologia de Povoamentos de Quercus pyrenaica Willd. em Portugal Continental. Dissertação de Doutoramento, UTAD, Vila Real. 213 p

Cienciala E, Tomppo E, Snorrason A, Broadmeadow M, Colin A, Dunger K, Exnerova Z, Lassere B, Petersson H, Priwitzer T, Sanchez G, Stahl G (2008) Preparing emission reporting form forests - use of National Forest Inventories ind European countries. Silva Fenn 42: 73-88. https://doi.org/10.14214/sf.265

COST Action E43 (2010) Harmonisation of National Forest Inventories in Europe - Techniques for common reporting. www.metla.fi/eu/ cost/e43/. Accessed 17 November 2016
COST Action FP1001 (2014) Improving data and information on the potential supply of wood resources - A European approach from multisource National Forest Inventories. https://sites.google.com/ site/costactionfp 1001/. Accessed 19 January 2018

Čokl M (1957) Prirejene Alganove in Schafferjeve tarife ter njihova raba pri inventraizaciji sestojev. $=$ Adjusted Algan and Schaffer tariffs and their use in the inventory of forest stands. ZbGL 2:165-195

Dagnelie P, Palm R, Rondeux J (2013) Cubage des arbres et des peuplements forestiers. Tables et équations. Presses agronomiques de Gembloux, $176 \mathrm{p}$

DIABOLO (2015) Distributed, Integrated And Harmonised Forest Information For Bioeconomy Outlooks. http://diabolo-project.eu/. Accessed 19 January 2018

Dunger K, Petersson SHO, Barreiro S, Cienciala E, Colin A, Hylen G, Kusar G, Oehmichen K, Tomppo E, Tuomainen T, Stahl G (2012) Harmonizing greenhouse gas reporting from European forests: case examples and implications for European Union level reporting. For Sci 58:248-256. https://doi.org/10.5849/forsci.10-064

EC (2003) Natura 2000 and forests 'challenges and opportunities'-interpretation guide. Office for Official Publications of the European Communities, Luxembourg

EFICS (1997) Study on European forestry information and communication system - reports on forest inventory and survey systems, volumes 1 and 2. European Communities 1997, Luxembourg

ENFIN (2018) European national forest inventory network. Available online at www.enfin.info. Accessed 19 January 2018

Eriksson H (1973) Volymfunktioner för stående träd av ask, asp, klibbal och contorta-tall. Skogshögskolan, Inst. f. skogsproduktion, Rapporter och Uppsatser 26, Stockholm, $26 \mathrm{p}$

European Commission (2015) Report on the status of and trends for habitat types and species covered by the birds and habitats directives for the 2007-2012 period as required under article 17 of the habitats directive and article 12 of the birds directive, Brussels $19 \mathrm{p}$

European Parliament and Council of the European Union (2009) Directive 2009/28/EC on the promotion of the use of energy from renewable sources. Official Journal of the European Union

FAO (2001) The global forest resources assessment 2000 - main report. FAO Forestry Paper 140, Rome, $479 \mathrm{p}$

FAO (2004) Global forest resources assessment update 2005-terms and definitions. Forest Resources Assessment Programme, Working paper 83/E, $34 \mathrm{p}$

FAO (2010) Global forest resources assessment 2010 - terms and definitions. Forest Resources Assessment Programme, Working paper 144/E, $27 \mathrm{p}$

FAO (2012a) FRA 2015-terms and definitions. Forest Resources Assessment Working Paper 180, $31 \mathrm{p}$

FAO (2012b) Supporting sustainable forest management through global forest resources assessment: long-term strategy 2012-2030. Committee on Forestry, Twenty-first session. Rome, Italy, 24-28 September 2012. COFO/2012/7.3. $11 \mathrm{p}$

FAO (2015) Global forest resources assessment 2015 — desk reference. Forest Resources Assessment Programme, $245 \mathrm{p}$

FOREST EUROPE, UNECE and FAO (2011) State of Europe's Forests 2011. Status and Trends in Sustainable Forest Management in Europe. $337 \mathrm{p}$

FOREST EUROPE (2015) State of Europe's Forest 2015. Ministerial Conference on the Protection of Forests in Europe, FOREST EUROPE Liaison Unit Madrid, $312 \mathrm{p}$

Forest Service (2013) The second National Forest Inventory - Republic of Ireland - results. Department of Agriculture, Fisheries and the Marine. $265 \mathrm{p}$

Giurgiu V (1974) O expresie matematica unica a relatiei diametru inaltime - volum, pentru majoritatea speciilor forestiere din Romania. Silvicultura si Exploratarea Padurilor 89(4):173-178

Grigaliūnas J, Garbinčius A (1972) Stem form factor and volume models of the main tree species of Lithuania. Girios 12 (In Lithuanian) 
Gschwantner T, Schadauer K (2006) Branch biomass functions for broadleaved tree species in Austria. Aust J For Sci 123:17-34

Gschwantner T, Schadauer K, Vidal C, Lanz A, Tomppo E, Di Cosmo L, Robert N, Englert Duursma D, Lawrence M (2009) Common tree definitions for National Forest Inventories in Europe. Silva Fenn 43: 303-321. https://doi.org/10.14214/sf.463

Gschwantner T, Lanz A, Vidal C, Bosela M, Di Cosmo L, Fridman J, Gasparini P, Kuliešis A, Tomter S, Schadauer K (2016) Comparison of methods used in European National Forest Inventories for the estimation of volume increment: towards harmonisation. Ann For Sci 73:807-821. https://doi.org/10.1007/s13595-016-0554-5

Hagberg E , Matérn B (1975) Tabeller för kubering av ek och bok. Skogshögskolan, Inst. f. skoglig matematisk statistik, Rapporter och Uppsatser 14, Stockholm. $118 \mathrm{p}$

Henning L, Korhonen KT, Lanz A, Riedel T (2016) Final report, specific contract nr. 17 "Use of National Forest Inventories data to estimate biomass in the European forests" in the context of the "Framework contract for the provision for forest data and services in support to the European Forest data Centre". Joint Research Centre of the European Commission, Ispra, Italy

Hladnik D, Kobal M (2012) Ocenjevanje natančnosti deblovnic in volumenskih funkcij. = Estimating the accuracy of volume tables and volume equations for silver fir. ZbGL 98: 3-14

ICONA (1990) Segundo Inventario Forestal Nacional. Explicaciones y Métodos. Ministerio de Agricultura, Pesca y Alimentación. Servicio de Inventario Forestal

IFN2 (1986-1995) Segundo Inventario Forestal Nacional. Ministerio de Agricultura Pesca y Alimentación. Instituto Nacional para la Conservación de la Naturaleza. Tarifas elaboradas por el Servicio de Inventario Forestal

IPCC (2006) In: Eggleston HS, Buendia L, Miwa K, Ngara T, Tanabe K (eds) 2006 IPCC guidelines for national greenhouse gas inventories - volume 4: agriculture, forestry and other land use prepared by the National Greenhouse gas Inventories Programme. Institute for Global Environmental Strategies (IGES), Hayama

Jonson T (1928) Några nya metoder för beräkning av stamvolym och tillväxt hos stående träd. = Some new methods for calculating volume and increment of standing timber. Särtryck ur Skogshögskolans Festskrift 1928. Svenska Skogsvårdsföreningens Förlag

Kaufmann E (2001) Estimation of standing timber, growth and cut. In: Brassel P and Lischke H (eds) Swiss National Forest Inventory: methods and models of the second assessment. Birmensdorf, Swiss Federal Research Institute WSL. Pp. 162-196; new edition in press

Konôpka B, Pajtík J, Moravčík M, Lukac M (2010) Biomass partitioning and growth efficiency in four naturally regenerated forest tree species. Basic Appl Ecol 11:234-243. https://doi.org/10.1016/j.baae. 2010.02.004

Korhonen KT, Riedel T, Lanz A (2014) Final report, specific contract nr. 13 "use of National Forest Inventories data to estimate biomass in the European forests" in the context of the "framework contract for the provision for forest data and services in support to the European Forest data Centre". Joint Research Centre of the European Commission, Ispra, Italy

Kublin E (2003) Einheitliche Beschreibung der Schaftform - Methoden und Programm - BDATPro. $=$ A uniform description of stem profiles - methods and programs - BDATPro. Forstw Cbl 122:183-200

Kuliešis A, Kenstavičius J (1976) Modelling of stem form factors. Lesovedenije 3:85-91 (in Russian)

Kuliešis A, Gudas K (1989) The form and form factor models of aspen stems. Lesovedenije 4:42-50 (In Russian)

Kuliešis A, Kulbokas G (2009) Assessment of growing stock components for data harmonization in international reporting. Lithuanian case study. Balt For 15-1:58-64
Laasasenaho J (1976) Männyn, kuusen ja koivun kuutioimisyhtälöt. Lisensiaattityö. Helsingin yliopisto. Metsänarvioimistieteen laitos. $89 \mathrm{p}$

Laasasenaho J (1982) Taper curve and volume functions for pine, spruce and birch. Commun Inst For Fenn 108:1-74

Lanz A, Alberdi I, Barbati A, Barsoum N, Brändli U-B, Chirici G, Cienciala E, Condes S, Di Cosmo L, Freudenschuss A, Gabler K, Gschwantner T, Hylen G, Ilvesniemi H, Kusar G, Kändler G, Lawrence M, McRoberts RE, Nabuurs G-J, Petersson H, Priwitzer T, Robert N, Rondeux J, Schadauer K, Ståhl G, Tomter S, Tomppo E, Tosi V, Vidal C, Weiss P, Winter S (2010) A sample of COST action E43 reference definitions. In: Tomppo E et al (eds) National Forest Inventories - pathways for common reporting. Springer, New York, pp 595-607

Lanz A (2012) Estimators for the E-Forest platform. Ver. 1.11, 6 November 2012. Annex to the final report, specific contract n. 8 "Statistical calculations at European level using design based estimators" in the context of the "Framework contract for the provision of forest data and services in support to the European Forest data Centre". Joint Research Centre of the European Commission, Ispra, Italy

Lesprojekt (1952) Hmotové tabulky ÚLT (Volume Tables ULT). Brandýs nad Labem

Liepa I (1996) Pieauguma mācība (increment teaching). LLU, Jelgava 123 p. (in Latvian)

Madsen SF (1985) Compatible tree taper and volume functions for five different conifers (in Danish with English summary). Det Forstl Forsøgsvæs Dan 40:97-140

Madsen SF (1987) Volume equations for some important Danish forest tree species. Det Forstl Forsøgsvæs 40:47-242

Madsen SF, Heusèrr M (1993) Volume and stem-taper functions for Norway spruce in Denmark. Forest Landsc Res 1:51-78

Mantau U, Gschwantner T, Paletto A, Mayr ML, Blanke C, Strukova E, Avdagic A, Camin P, Thivolle-Cazat A, Döring P, Petrauskas E, Englert H, Schadauer K, Barreiro S, Lanz A, Vidal C (2016) From inventory to consumer biomass availability - the ITOC model. Ann For Sci 73:885-894. https://doi.org/10.1007/s13595-016-0582-1

Marklund LG (1988) Biomassafunktioner för tall, gran och björk i Sverige. Sveriges lantbruksuniversistet, Institutionen för skogstaxering, Rapport $45.73 \mathrm{p}$

McRoberts RE, Ståhl G, Vidal C, Lawrence M, Tomppo E, Schadauer K, Chirici G, Bastrup-Birk A (2010) National Forest Inventories: prospects for harmonised international reporting. In: Tomppo E et al (eds) National Forest Inventories - pathways for common reporting. Springer, New York, pp 33-43

McRoberts RE, Winter S, Chirici G, LaPoint E (2012) Assessing forest naturalness. For Sci 58: 294-309. https://doi.org/10.5849/forsci.10075

MKJ (2009) Metsa korraldamise juhend [Forest inventory instruction]. Riigi Teataja lisa 2009(9):14

Morneau F, Hervé J-C (2010) Note technique: Tarifs de cubage à l'Inventaire forestier national. Internal document. IFN, Nogent-surVernisson, France 13 p. (in French)

Näslund M, Hagberg E (1950) Skogsforskningsinstitutets större tabeller för kubering av stående träd. Tall, gran och björk i södra Sverige. Statens Skogsforskningsinstitut, Experimentalfältet, Stockholm. $200 \mathrm{p}$

Ozolins R (2002) Forest stand assortment structure analysis using mathematical modelling. Forestry Studies/Metsanduslikud uurimused $37: 33-42$

Pantić D (1997a) Troulazne zapreminske tablice za hrast lužnjak u šumama Ravnog Srema, Šumarstvo 2. UŠITS, Beograd, pp 37-44 (in Serbian)

Pantić D (1997b) Troulazne zapreminske tablice za poljski jasen u šumama Ravnog Srema, Šumarstvo 4-5. UŠITS, Beograd, pp 6774 (in Serbian) 
Parez J, Žlábek I, Kopriva J (1990) Základní technické jednotky pro stanovení objemu dríví v težebním fondu hlavních lesních drevin. Lesnictví 36:479-508

Patrício MSF (2006) Análise da Potencialidade Produtiva do Castanheiro em Portugal. Dissertação de Doutoramento. Universidade Técnica de Lisboa, Instituto Superior de Agronomia, Lisboa

Paulo JA, Tomé M (2006) Equações para Estimação do Volume e Biomassa de Duas Espécies de Carvalhos: Quercus suber e Quercus ilex. Relatório científico do GIMREF. RC1/2006. Centro de Estudos Florestais, Instituto Superior de Agronomia, Lisboa

Petersson H, Ståhl G (2006) Functions for below-ground biomass of Pinus sylvestris, Picea abies, Betula pendula and Betula pubescens in Sweden. Scan J For Res 21(Suppl 7):84-93. https://doi.org/10. 1080/14004080500486864

Petráš R, Pajtík J (1991) Sústava česko-slovenských objemových tabuliek drevín. = Volume equations for tree species in Czechoslovakia. Lesn časopis 37:49-56

Pollanschütz J (1974) Formzahlfunktionen der Hauptbaumarten Österreichs. Allg Forstzitg 85:341-343

Prodan M (1965) Holzmesslehre. JD Sauerländer's Verlag, Frankfurt am Main $644 \mathrm{p}$

Riemer T, von Gadow K, Slodoba B (1995) Ein Modell zur Beschreibung von Baumschäften. Allg Forst Jagdztg 166(7):144-147

Sallnäs O, Berger A, Räty M, Trubins R (2015) An area-based matrix model for uneven-aged forests. Forests 6:1500-1515. https://doi. org/10.3390/f6051500

Schieler K (1988) Methodische Fragen in Zusammenhang mit der Österreichischen Forstinventur. Diplomarbeit an der Universität für Bodenkultur Wien, $99 \mathrm{p}$

Sopp L, Kolozs L (2000) Fatömegszámítási táblázatok. Állami Erdészeti Szolgálat, Budapest

Ståhl G, Cienciala E, Chirici G, Lanz A, Vidal C, Winter S, McRoberts RE, Rondeux J, Schadauer K, Tomppo E (2012) Bridging national and reference definitions for harmonising forest statistics. For Sci 58:214-223. https://doi.org/10.5849/forsci.10-067

Tarp-Johansen MJ, Skovsgaard JP, Madsen SF, Johannsen VK, Skovgaard I (1997) Compatible stem taper and stem volume functions for oak (Quercus robur $\mathrm{L}$ and $Q$ petraea (Matt) Liebl) in Denmark. Ann For Sci 54:577-595. https://doi.org/10.1051/forest: 19970701

Tomé M, Tomé J, Ribeiro F, Faias S (2007a) Equações de volume total, volume percentual e deperfil do tronco para EucalyptusglobulusLabill. em Portugal. Silva Lusit 15(1):25-40

Tomé M, Faias SP, Correia A (2007b) Equações de biomassa e de volume desenvolvidas no âmbito do tratamento dos dados do Inventário Florestal Nacional 2005-2006.PublicaçõesGIMREF. RT 4/2007.
Universidade Técnica de Lisboa, Instituto Superior de Agronomia, Centro de Estudos Florestais, Lisboa

Tomppo E, Gschwantner T, Lawrence M, McRoberts RE (eds) (2010a) National Forest Inventories - pathways for common reporting. Springer, New York, 612 p. https://doi.org/10.1007/978-90-4813233-1

Tomppo E, Schadauer K, McRoberts RE, Gschwantner T, Gabler K, Ståhl G (2010b) Introduction. In: Tomppo E et al (eds) National Forest Inventories - pathways for common reporting. Springer, New York, pp 1-18

Tomppo E, Schadauer K (2012) Harmonisation of National Forest Inventories in Europe - advances under COST Action E43. For Sci 58:191-200. https://doi.org/10.5849/forsci.12-042

Tomter SM, Gasparini P, Gschwantner T, Hennig P, Kulbokas G, Kuliesis A, Polley H, Robert N, Rondeux J, Tabacchi G, Tomppo E (2012) Establishing bridging functions for harmonising growing stock estimates - examples from European National Forest Inventories. For Sci 58:224-235. https://doi.org/10.5849/forsci.10-068

United Nations (1998) Kyoto protocol to the United Nations framework convention on climate change. United Nations, $20 \mathrm{p}$. http://unfccc. int/resource/docs/convkp/kpeng.pdf. Accessed 30 Jan 2019

United Nations (1992) United Nations Framework Convention on Climate Change. 33 p. https://unfccc.int/resource/docs/convkp/ conveng.pdf. Accessed 30 Jan 2019

UNECE/FAO (2000) Forest resources of Europe, CIS, North America, Australia, Japan and New Zealand. Geneva timber and forest study papers No 17. United Nations, New York and Geneva. $445 \mathrm{p}$

UNECE/FAO (2011) The European Forest sector outlook study II. UNECE/FAO Forestry and Timber Section, Geneva, $111 \mathrm{p}$

Vestjordet E (1967) Funksjoner og tabeller for kubering av stående gran. Medd nor Skogforsok 22:539-574

Vidal C, Lanz A, Tomppo E, Schadauer K, Gschwantner T, di Cosmo L, Robert N (2008) Establishing forest inventory reference definitions for forest and growing stock: a study towards common reporting. Silva Fenn 42:247-266. https://doi.org/10.14214/sf.255

Vidal C, Alberdi I, Hernández L, Redmond J (2016a) National Forest Inventories - assessment of wood availability and use. 845 p. https://doi.org/10.1007/978-3-319-44015-6

Vidal C, Alberdi I, Redmond J, Vestman M, Lanz A, Schadauer K (2016b) The role of European National Forest Inventories for international forestry reporting. Ann For Sci 73:793-806. https://doi.org/ 10.1007/s13595-016-0545-6

Winter S, Chirici G, McRoberts RE, Hauk E, Tomppo E (2008) Possibilities for harmonizing national forest inventory data for use in forest biodiversity assessments. Forestry $81(1): 33-44$. https://doi. org/10.1093/forestry/cpm042 


\section{Affiliations}

Thomas Gschwantner ${ }^{1}$. Iciar Alberdi ${ }^{2} \cdot$ András Balázs $^{3} \cdot$ Sébastien Bauwens ${ }^{4} \cdot$ Susann Bender ${ }^{5} \cdot$ Dragan Borota $^{6}$. Michal Bosela ${ }^{7,8}$. Olivier Bouriaudd ${ }^{9}$. Isabel Cañellas ${ }^{2}$ • Jānis Donis ${ }^{10}$ - Alexandra Freudenschuß ${ }^{1}$.

Jean-Christophe Hervé ${ }^{11}$ • David Hladnik ${ }^{12,13}$. Jurǵis Jansons ${ }^{10} \cdot$ László Kolozs $^{14} \cdot$ Kari T. Korhonen $^{3} \cdot$ Milos Kucera $^{15}$. Gintaras Kulbokas $^{16,17}$. Andrius Kuliešis ${ }^{16,17}$. Adrian Lanz ${ }^{18}$. Philippe Lejeune ${ }^{4}$. Torgny Lind ${ }^{19}$. Gheorghe Marin ${ }^{9}$. François Morneau ${ }^{20}$ - Dóra Nagy ${ }^{14}$. Thomas Nord-Larsen ${ }^{21}$ • Leónia Nunes ${ }^{22}$ - Damjan Pantić ${ }^{6}$. Joana A. Paulo ${ }^{23}$. Tomas Pikula $^{15}$ • John Redmond ${ }^{24}$ • Francisco C. Rego ${ }^{22} \cdot$ Thomas Riedel $^{5}$ - Laurent Saint-André ${ }^{25}$. Vladimír Šebeň ${ }^{7}$. Allan Sims ${ }^{26}$. Mitja Skudnik ${ }^{13}$ - György Solti ${ }^{14}$ - Stein M. Tomter ${ }^{27}$. Mark Twomey ${ }^{24}$ • Bertil Westerlund ${ }^{19}$. Jürgen Zell ${ }^{18}$

1 Federal Research and Training Centre for Forests, Natural Hazards and Landscape (BFW), Seckendorff-Gudent-Weg 8,

1131 Vienna, Austria

2 Forest Research Centre of the National Institute for Agricultural and Food Research and Technology (INIA-CIFOR), Carretera de la Coruna, 28040 Madrid, Spain

3 Natural Resources Institute Finland (Luke), Latokartanonkaari 9, 00790 Helsinki, Finland

4 TERRA-Forest is Life, Gembloux Agro-Bio Tech, University of Liège, Passage de Déportés 2, 5030 Gembloux, Belgium

5 Thünen Institute of Forest Ecosystems (TI), Alfred-Möller-Straße 1, 16225 Eberswalde, Germany

6 Faculty of Forestry, University of Belgrade, Kneza Viseslava 1, 11030 Belgrade, Serbia

7 National Forest Centre (NFC), T.G. Masaryka 22, 96092 Zvolen, Slovakia

8 Technical University in Zvolen, T.G. Masaryka 24, 96053 Zvolen, Slovakia

9 Forest Research and Management Institute (ICAS), Calea Bucovinei 73b, 725100 Campulung Moldovenesc, Romania

10 Latvian State Forest Research Institute "Silava" (LSFRI), Rigas str. 111, 2169 Salaspils, Latvia

11 Institut National de l'Information Géographique et Forestière (IGN), Forest Inventory laboratory, 14 rue Girardet, 54042 Nancy, France

12 Biotechnical Faculty, Department of Forestry and Renewable Forest Resources, University of Ljubljana (UL), Večna pot 83, 1000 Ljubljana, Slovenia

13 Department of Forest and Landscape Planning and Monitoring, Slovenian Forestry Institute (SFI), Večna pot 2, 1000 Ljubljana, Slovenia
14 National Food Chain Safety Office (NÉBIH), Keleti Károly utca 24, 1024 Budapest, Hungary

15 Forest Management Institute (UHUL), Nábrezni 1326, 25001 Brandýs nad Ladem, Czech Republic

16 Aleksandras Stulginskis University (ASU), Studentu str. 11, Akademija, 53361 Kauno R, Lithuania

17 Lithuanian State Forest Service (LSFS), Pramones av. 11a, 51327 Kaunas, Lithuania

18 Swiss Federal Institute for Forest, Snow and Landscape Research (WSL), Zürcherstrasse 111, 8903 Birmensdorf, Switzerland

19 Swedish University of Agricultural Sciences (SLU), Skogsmarksgränd, 90183 Umeå, Sweden

20 Institut National de l'Information Géographique et Forestière (IGN), Forest Inventory service, Château des Barres, 45290 Nogent-sur-Vernisson, France

21 University of Copenhagen (UCPH), Rolighedsvej 23, 1958 Frederiksberg C, Denmark

22 Centre for Applied Ecology "Professor Baeta Neves" (CEABN), InBio, School of Agriculture, University of Lisbon, Tapada da Ajuda, 1349-017 Lisbon, Portugal

23 Forest Research Centre, School of Agriculture, University of Lisbon, Tapada da Ajuda, 1349-017 Lisbon, Portugal

24 Forest Service (FS), Department of Agriculture, Food and the Marine, Kildare Street - Agriculture House, Dublin 2, Ireland

25 Institut National de la Recherche Agronomique (INRA), Rue d'Amance, 54280 Champenoux, France

26 Estonian Environment Agency (ESTEA), Tallinn, Estonia

27 Norwegian Institute of Bioeconomy Research (NIBIO), Høgskoleveien 8, 1433 Ås, Norway 